\title{
Recent Changes in U.S. Family Finances: Evidence from the 1998 and 2001 Survey of Consumer Finances
}

Ana M. Aizcorbe, Arthur B. Kennickell, and Kevin B. Moore, of the Board's Division of Research and Statistics, prepared this article with assistance from Ryan M. Bledsoe, Gerhard Fries, and L. Brooke Wells.

Data from the Federal Reserve Board's Survey of Consumer Finances show a striking pattern of growth in family income and net worth between 1998 and 2001. Inflation-adjusted incomes of families rose broadly, although growth was fastest among the group of families whose income was higher than the median. The median value of family net worth grew faster than that of income, but as with income, the growth rates of net worth were fastest for the group above the median. The years between 1998 and 2001 also saw a rise in the proportion of families that own corporate equities either directly or indirectly (such as through mutual funds or retirement accounts); by 2001 the proportion exceeded 50 percent. The growth in the value of equity holdings helped push up financial assets as a share of total family assets despite a decline in the overall stock market that began in the second half of 2000 .

The level of debt carried by families rose over the period, but the expansion in equities and the increased values of principal residences and other assets were sufficient to reduce debt as a proportion of family assets. The typical share of family income devoted to debt repayment also fell over the period. For some groups, however - particularly those with relatively low levels of income and wealth-a concurrent rise in the frequency of late debt payments indicated that their ability to service their debts had deteriorated.

This article reviews these and other changes in the financial condition of U.S. families between 1998 and 2001. ${ }^{\perp}$ The discussion draws on data from the Federal Reserve Board's Survey of Consumer Finances

1. The appendix to this article provides a summary of key technical aspects of the survey. For a detailed discussion of the 1995 and 1998 surveys as well as references to earlier surveys, see Arthur B. Kennickell, Martha Starr-McCluer, and Brian J. Surette, "Recent Changes
(SCF) for those years; it also uses evidence from earlier years of the survey to place the 1998-2001 changes in a broader context.

\section{ECONOMIC BACKGROUND}

After growing rapidly for several years, real (inflation-adjusted) gross domestic product increased at a more moderate 2.3 percent rate in 2000 . Between 1998 and 2000, the increase in overall economic activity was sufficiently strong to lower the unemployment rate from 4.5 percent to 4.0 percent. In part because of a run-up in energy prices, the rate of inflation as measured by the consumer price index for all urban consumers (CPI) rose from 1.5 percent to 3.4 percent.

Real GDP actually declined through the first three quarters of 2001, before turning up in the fourth quarter, and for the year as a whole, real GDP was essentially unchanged. The unemployment rate jumped to 4.8 percent during the year-close to its level in early 1998 - and the CPI inflation rate fell to 1.9 percent, the same pace as for 1998 .

Developments in the financial sector during the 1998-2001 period were mixed. The stock market decline over much of 2000 and 2001 reversed gains posted earlier, and by the end of $200 \mathrm{l}$ it had brought most major indexes close to their 1998 levels. Interest rates on mortgages followed a similar pattern. For example, the thirty-year fixed rate rose over the late 1990 s, but by September 2001 (the middle of the data collection period for the 2001 survey), it had returned to the 6\%/4 percent level seen in September 1998. By September 2001, interest rates for loans on new vehicles and for credit card balances were below their 1998 levels. Interest rates on deposits had dropped below 3 percent by 2001. While the homeownership rate rose moderately over the period, house prices

in U.S. Family Finances: Results from the 1998 Survey of Consumer Finances," Federal Reserve Bulletin, vol. 86 (January 2000), pp. 1-29. 


\section{The Data Used in This Article}

Data from the Survey of Consumer Finances (SCF) are the basis of the analysis presented in this article. The SCF is a triennial interview survey of U.S. families sponsored by the Board of Governors of the Federal Reserve System with the cooperation of the U.S. Department of the Treasury. Since 1992, data for the SCF have been collected by NORC, a research organization at the University of Chicago, roughly between May and December of each survey year.

The majority of statistics included in this article are related to characteristics of "families." As used here, this term is more comparable to the U.S. Bureau of the Census definition of "households" than to their use of "families," which excludes the possibility of one-person families. The appendix provides full definitions of "family" for the SCF and the associated family "head." The survey is designed to provide detailed information on U.S. families' balance sheets and their use of financial services as well as on their pensions, labor force participation, and demographic characteristics as of the time of the interview. It also collects information on families' total cash income before taxes for the calendar year preceding the survey. The survey questionnaire has changed in only minor ways since 1989 , except in a small number of instances in which the structure was altered to accommodate changes in financial behaviors. Thus, the data are highly comparable over time.

The need to measure financial characteristics imposes special requirements on the sample design for the survey. The SCF is expected to provide reliable information both on attributes that are broadly distributed in the population (such as home ownership) and on those that are highly concentrated in a relatively small part of the population (such as closely held businesses). To address this requirement, the SCF employs a sample design, essentially unchanged since 1989, consisting of two parts: a standard, geographically based random sample and a special oversample of relatively wealthy families. Weights are used to combine information from the two samples to make estimates for the full population. In the 1998 survey, 4,309 families were interviewed, and in the 2001 survey, 4,449 were interviewed.

This article draws principally upon the final data from the 1998 and 2001 surveys. To provide a larger context, some information is also included from the final versions of the 1992 and 1995 surveys. Differences between estimates from earlier surveys as reported here and as reported in earlier Federal Reserve Bulletin articles are attributable to additional statistical processing, correction of minor data errors, revisions to the survey weights, conceptual changes in the definitions of variables used in the articles, and adjustments for inflation. In this article, all dollar amounts from the
SCF are adjusted to 2001 dollars using the "current methods" version of the consumer price index (CPI) for all urban consumers. ${ }^{1}$ Because the current-methods index shows a lower rate of past price inflation than does the official CPI, upward adjustments for inflation made to the pre-2001 nominal values are smaller than they would have been under the official CPI.

The principal detailed tables describing asset and debt holdings focus on the percent of various groups that have such items and the median holding for those that have them. ${ }^{2}$ This conditional median is chosen to give a sense of the "typical" holding. Generally, when one deals with data that exhibit very large values for a relatively small part of the population - as is the case for many of the items considered in this article estimates of the median are often statistically less sensitive to such outliers than are estimates of the mean. One liability of using the median as a descriptive device is that medians are not "additive"; that is, the sum of the medians of two items for a common population is not generally equal to the median of the sum. In contrast, means for a common population are additive. In tables where a comparable median and mean are given, the growth of the mean relative to the median may usually be taken as indicative of change at the top of the distribution; for example, when the mean grows more rapidly than the median, it is typically taken to indicate that the values comprised by the top of the distribution rose more rapidly than those in the lower part of the distribution.

To provide a measure of the significance of the developments discussed in this article, standard errors due to sampling are given for selected estimates. ${ }^{3}$ Space limits prevent the inclusion of the standard errors for all estimates. Although we do not directly address the statistical significance of the results, the article highlights findings that are significant or are interesting in a broader context.

1. In an ongoing effort to improve accuracy, the Bureau of Labor Statistics has introduced several revisions to its CPI methodology. The currentmethods index attempts to extend these changes to earlier years to obtain a series as consistent as possible with current practices in the official CPI. For technical information about the construction of this index, see Kenneth J. Stewart and Stephen B. Reed, "Consumer Price Index Research Series Using Current Methods, 1978-1998," Monthly Labor Review, vol. 122 (June 1999), pp. $29-38$. To adjust assets and liabilities to 2001 dollars, the earlier survey data were multiplied by the following amounts: for 1992, 1.2374; for 1995 , 1.1558 ; and for $1998,1.0885$. To adjust family income for the previous calendar year to 2001 dollars, the following factors were applied: for 1992 , 1.2675 ; for $1995,1.1815$; for $1998,1.0998$; and for $2001,1.0279$

2. The median of a distribution is defined as the value at which equal parts of the population considered have values larger or smaller.

3. As noted in the appendix, these standard errors are estimated with a procedure different from that employed in earlier articles on the survey. climbed steadily; some indexes of house prices gained nearly 25 percent.

Other institutional factors also affected family finances. Tax cuts and rebates that were implemented in 2001 lowered the income tax burden beginning that year. Other changes in tax law expanded incentives for saving; of particular note were increases in the limits on contributions to individual retirement 
accounts (IRAs) and 401(k) accounts. At the same time, the first in a series of estate tax reductions was implemented. Increases in education-related tax credits also held down the tax payments of families. Continuing growth of the Internet made financial information and tools for financial management more widely available; according to the SCF the fraction of families who used such resources about doubled between 1998 and 2001, but the overall rate of use remained less than 25 percent of families.

Ongoing demographic trends continued to change the structure of the population. Overall population growth was about 3.2 percent between 1998 and 2001; about 45 percent of the increase was due to net immigration. With the aging of the baby-boom population, the number of people aged 45 to 64 grew more than 10 percent. The number of households grew 4.1 percent-a rate faster than the 3.6 percent pace in the 1995-98 period-while the average number of people per household remained close to two.

\section{FAMILY INCOME}

Between 1998 and 2001, inflation-adjusted family incomes rose notably faster than they did in the 1995-98 period (see table 1 for dollar values): The median rose 9.6 percent $(2.5$ percent during the 1995-98 period), and the mean rose 17.4 percent (12.2 percent during the $1995-98$ period). ${ }^{2}$ The Current Population Survey (CPS) of the Bureau of the Census reports growth in median income for the 1998-2001 period that is similar to the growth shown in the SCF, but at a somewhat higher level. ${ }^{3}$

Some patterns of income across family groups hold consistently, or nearly so, in the four surveys taken in the nine-year period between 1992 and 2001. Across age classes, median and mean income show the expected life-cycle pattern: They rise to a peak in the 45-54 group and then decline for groups that are older and increasingly more likely to be retired. Income also rises with education, and incomes for family heads that have a college degree are substan-

2. To measure income, the interviewers request information on all components of the family's cash income, before taxes, for the full calendar year preceding the interview (see box "The Data Used in This Article"). Hence, references in the text and tables of this article to income reported from the survey years 1992, 1995, 1998, and 2001 cover the income received in $1991,1994,1997$, and 2000 respectively.

3. According to the CPS, median household income for the twelve months preceding March 2001 was $\$ 42,200$. The difference in the levels of the medians in the two surveys appears to be largely explained by differences in the way the surveys treat incomes of household members. Under the SCF definition of family, household members (and their respective incomes) may belong to different families (see the appendix for details), whereas the CPS household measure includes the incomes of all household members. In addition, mean income is substantially higher in the SCF than in the CPS, tially higher than for those with any lesser amount of schooling. Incomes of white non-Hispanic families are substantially higher than those of other families. ${ }^{4}$ Families headed by self-employed workers have the highest median and mean incomes of all work-status groups. Income is also higher for homeowners than for other families, and it is progressively higher for groups with greater net worth. By region of the country, the ordering of median incomes over time has varied, but the means show consistently higher values for the Northeast and West than for the North Central and South.

\section{Income by Demographic Category}

Incomes grew at different rates in different parts of the income distribution between 1998 and 2001, with faster growth at both the top and the bottom of the ranges than in the middle. During this period, the median income of families in the lowest 20 percent of the income distribution grew 14.4 percent; for the middle group (40th to 60th percentiles), it rose 9.6 percent; and for those in the highest group (90th to 100 th percentiles), it rose 19.3 percent. A similar pattern holds for the 1992-2001 period.

By age group, median income rose between 1998 and 2001 for all except the 45-54 group, for which it declined 1.3 percent. In percentage terms, the greatest increase was for the 75-and-older group-a rise of 23.1 percent; income for this group had been fairly flat from 1992 through 1998. Mean income grew for all age groups between 1998 and 2001, but particularly so -22.6 percent - for the $45-54$ group.

primarily because the CPS truncates incomes above a certain amount to obscure respondents who might otherwise be identifiable.

4. The race and ethnicity of members of a single family may vary; this article categorizes the family as a whole according to the selfidentification of the respondent to the $\overline{S C F}$ interview. The $S \overline{C F}$ question that is used to identify race and Hispanic origin was changed in 1998. In earlier surveys, respondents were asked to choose a single category that best described their race or ethnicity. In 1998, respondents could choose as many as seven responses, but they were asked to report first the category with which they identified most.

For comparability with the earlier surveys, this article uses only the first response to the race and ethnicity questions for the 1998 and 2001 surveys. Only a few of the survey respondents gave more than one response, and more complex treatments of the data do not yield conclusions that are substantively different from those reported in this article.

The estimated proportion of families that are of Hispanic origin in the $2001 \mathrm{SCF}$ is lower than an estimate based on the CPS, most likely because the CPS, unlike the SCF, asks directly about ethnicity in a question separate from the one that asks about race. Thus, in the CPS, respondents who do not normally identify themselves as Hispanic might provide an ethnic origin that is later classified as Hispanic. The proportions of families of Asian and Native American origin in the SCF are smaller than those obtained from the CPS, most likely because of sampling error. The SCF estimate of the proportion of African Americans is close to an estimate based on the CPS data. 
1. Before-tax family income, percentage of families who saved, and distribution of families, by selected characteristics of: families, 1992, 1995, 1998, and 2001 surveys

Thousands of 2001 dollars except as noted

\begin{tabular}{|c|c|c|c|c|c|c|c|c|}
\hline \multirow[b]{2}{*}{$\begin{array}{c}\text { Familv } \\
\text { characteristic }\end{array}$} & \multicolumn{4}{|c|}{155} & \multicolumn{4}{|c|}{1095} \\
\hline & Median & Mean & $\begin{array}{l}\text { Percentage } \\
\text { of } \\
\text { families } \\
\text { who saved }\end{array}$ & $\begin{array}{l}\text { Percentage } \\
\text { of } \\
\text { families }\end{array}$ & Median & Mean & $\begin{array}{l}\text { Percentage } \\
\text { of } \\
\text { families } \\
\text { who saved }\end{array}$ & $\begin{array}{l}\text { Percentage } \\
\text { of } \\
\text { families }\end{array}$ \\
\hline All families ....... & $\begin{array}{c}33.0 \\
(.7)\end{array}$ & $\begin{array}{r}49.5 \\
(.7)\end{array}$ & 57.1 & 100 & $\begin{array}{r}35.5 \\
(.9)\end{array}$ & $\begin{array}{r}\mathbf{5 1 . 6} \\
(.8)\end{array}$ & 55.2 & 100 \\
\hline 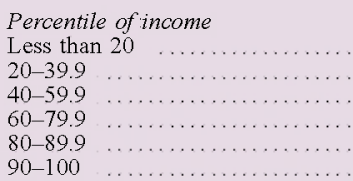 & $\begin{array}{r}8.4 \\
19.6 \\
33.0 \\
52.3 \\
78.0 \\
133.2\end{array}$ & $\begin{array}{r}8.1 \\
19.6 \\
33.6 \\
53.5 \\
79.5 \\
186.0\end{array}$ & $\begin{array}{l}30.2 \\
49.1 \\
59.2 \\
70.0 \\
71.6 \\
82.0\end{array}$ & $\begin{array}{l}20.0 \\
20.0 \\
20.0 \\
20.0 \\
10.0 \\
10.0\end{array}$ & $\begin{array}{r}8.0 \\
20.3 \\
35.5 \\
52.7 \\
79.3 \\
130.1\end{array}$ & $\begin{array}{r}7.7 \\
20.3 \\
34.8 \\
53.5 \\
80.4 \\
202.6\end{array}$ & $\begin{array}{l}31.6 \\
43.4 \\
57.2 \\
66.8 \\
69.9 \\
84.2\end{array}$ & $\begin{array}{l}20.0 \\
20.0 \\
20.0 \\
20.0 \\
10.0 \\
10.0\end{array}$ \\
\hline 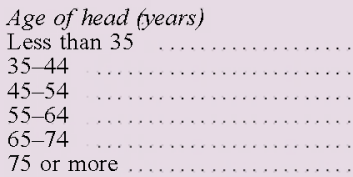 & $\begin{array}{l}30.4 \\
44.4 \\
51.6 \\
36.8 \\
22.1 \\
17.0\end{array}$ & $\begin{array}{l}37.5 \\
57.7 \\
70.2 \\
61.4 \\
35.9 \\
28.9\end{array}$ & $\begin{array}{l}59.1 \\
56.9 \\
59.0 \\
59.2 \\
54.0 \\
49.4\end{array}$ & $\begin{array}{r}25.8 \\
22.8 \\
16.2 \\
13.2 \\
12.6 \\
9.4\end{array}$ & $\begin{array}{l}29.6 \\
44.3 \\
46.5 \\
39.1 \\
22.3 \\
18.5\end{array}$ & $\begin{array}{l}36.1 \\
56.4 \\
76.4 \\
62.3 \\
43.3 \\
30.7\end{array}$ & $\begin{array}{l}56.4 \\
54.3 \\
58.0 \\
58.0 \\
50.0 \\
51.7\end{array}$ & $\begin{array}{r}24.8 \\
23.0 \\
17.9 \\
12.5 \\
12.0 \\
9.8\end{array}$ \\
\hline $\begin{array}{l}\text { Education of head } \\
\text { No high school diploma } \quad \ldots \ldots \ldots \\
\text { High school diploma } \quad \ldots \ldots \ldots \ldots \ldots \\
\text { Some college } \quad \ldots \ldots \ldots \ldots \ldots \ldots \ldots \\
\text { College degree } \quad \ldots \ldots \ldots \ldots \ldots \ldots\end{array}$ & $\begin{array}{l}15.2 \\
29.5 \\
34.3 \\
55.8\end{array}$ & $\begin{array}{l}21.6 \\
37.2 \\
45.8 \\
81.1\end{array}$ & $\begin{array}{l}38.1 \\
56.8 \\
59.5 \\
68.1\end{array}$ & $\begin{array}{l}20.4 \\
30.0 \\
17.8 \\
31.9\end{array}$ & $\begin{array}{l}16.8 \\
30.1 \\
35.5 \\
52.9\end{array}$ & $\begin{array}{l}24.2 \\
40.4 \\
46.9 \\
82.5\end{array}$ & $\begin{array}{l}42.8 \\
50.6 \\
54.1 \\
68.2\end{array}$ & $\begin{array}{l}18.5 \\
31.7 \\
19.0 \\
30.7\end{array}$ \\
\hline $\begin{array}{l}\text { Race or ethnicity of respondent } \\
\text { White non-Hispanic } \ldots \ldots \ldots \ldots \ldots \\
\text { Nonwhite or Hispanic } \quad \ldots \ldots \ldots \ldots\end{array}$ & $\begin{array}{l}38.1 \\
22.8\end{array}$ & $\begin{array}{l}54.7 \\
33.7\end{array}$ & $\begin{array}{l}61.1 \\
44.9\end{array}$ & $\begin{array}{l}75.3 \\
24.7\end{array}$ & $\begin{array}{l}38.2 \\
23.0\end{array}$ & $\begin{array}{l}56.7 \\
33.8\end{array}$ & $\begin{array}{l}59.1 \\
41.7\end{array}$ & $\begin{array}{l}77.6 \\
22.4\end{array}$ \\
\hline $\begin{array}{l}\text { Current work status of head } \\
\text { Working for someone else } \ldots \ldots \\
\text { Self-employed } \ldots \ldots \ldots \ldots \ldots \\
\text { Retired } \ldots \ldots \ldots \ldots \ldots \\
\text { Other not working } \ldots \ldots \ldots \ldots \ldots\end{array}$ & $\begin{array}{l}42.6 \\
55.5 \\
18.8 \\
14.0\end{array}$ & $\begin{array}{l}54.2 \\
94.3 \\
28.4 \\
25.9\end{array}$ & $\begin{array}{l}63.2 \\
59.4 \\
48.2 \\
41.3\end{array}$ & $\begin{array}{r}54.8 \\
10.9 \\
26.0 \\
8.3\end{array}$ & $\begin{array}{l}42.6 \\
43.8 \\
19.4 \\
13.0\end{array}$ & $\begin{array}{l}55.9 \\
92.5 \\
32.3 \\
21.5\end{array}$ & $\begin{array}{l}60.4 \\
63.4 \\
46.1 \\
30.6\end{array}$ & $\begin{array}{r}58.3 \\
10.3 \\
25.0 \\
6.5\end{array}$ \\
\hline $\begin{array}{l}\text { Region } \\
\text { Northeast } \ldots \ldots \ldots \ldots \ldots \ldots \ldots \\
\text { North Central } \ldots \ldots \ldots \ldots \ldots \ldots \ldots \\
\text { South } \ldots \ldots \ldots \ldots \ldots \ldots \ldots \ldots \ldots \ldots \ldots \\
\text { West } \ldots \ldots \ldots \ldots \ldots \ldots \ldots \ldots \ldots \ldots\end{array}$ & $\begin{array}{l}41.1 \\
35.8 \\
29.2 \\
32.7\end{array}$ & $\begin{array}{l}57.3 \\
51.0 \\
42.1 \\
52.5\end{array}$ & $\begin{array}{l}57.5 \\
61.3 \\
54.2 \\
56.4\end{array}$ & $\begin{array}{l}20.2 \\
24.4 \\
34.6 \\
20.9\end{array}$ & $\begin{array}{l}35.5 \\
36.2 \\
32.8 \\
36.7\end{array}$ & $\begin{array}{l}56.9 \\
52.6 \\
47.7 \\
51.8\end{array}$ & $\begin{array}{l}52.6 \\
59.2 \\
54.6 \\
54.0\end{array}$ & $\begin{array}{l}19.8 \\
23.9 \\
35.1 \\
21.2\end{array}$ \\
\hline $\begin{array}{l}\text { Housing status } \\
\text { Owner } \ldots \ldots \ldots \ldots \ldots \ldots \ldots \ldots \ldots \ldots \\
\text { Renter or other } \ldots \ldots \ldots \ldots \ldots \ldots \ldots\end{array}$ & $\begin{array}{l}43.1 \\
21.2\end{array}$ & $\begin{array}{l}60.6 \\
29.8\end{array}$ & $\begin{array}{l}63.2 \\
46.2\end{array}$ & $\begin{array}{l}63.9 \\
36.1\end{array}$ & $\begin{array}{l}43.8 \\
21.3\end{array}$ & $\begin{array}{l}63.9 \\
29.0\end{array}$ & $\begin{array}{l}61.3 \\
44.0\end{array}$ & $\begin{array}{l}64.7 \\
35.3\end{array}$ \\
\hline 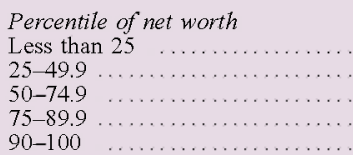 & $\begin{array}{r}16.1 \\
30.2 \\
40.6 \\
53.2 \\
100.1\end{array}$ & $\begin{array}{r}21.5 \\
34.2 \\
45.1 \\
62.9 \\
148.8\end{array}$ & $\begin{array}{l}37.4 \\
52.4 \\
63.5 \\
70.8 \\
81.0\end{array}$ & $\begin{array}{l}25.0 \\
25.0 \\
25.0 \\
15.0 \\
10.0\end{array}$ & $\begin{array}{l}16.7 \\
33.1 \\
41.0 \\
49.4 \\
93.0\end{array}$ & $\begin{array}{r}21.5 \\
36.2 \\
47.1 \\
61.1 \\
162.2\end{array}$ & $\begin{array}{l}35.8 \\
51.4 \\
59.5 \\
68.6 \\
82.4\end{array}$ & $\begin{array}{l}25.0 \\
25.0 \\
25.0 \\
15.0 \\
10.0\end{array}$ \\
\hline
\end{tabular}

Across education groups, median and mean incomes rose most strongly for families headed by persons with a college degree; median income for this group rose 13.4 percent, and the mean rose 25.1 percent. Median income also rose for other education groups except for families headed by persons without a high school diploma or its equivalent, a group that had seen little change in income since 1992; among these education groups, mean income rose most notably for the group with at least some college education.

Between 1998 and 2001, the median income of nonwhite or Hispanic families was about unchanged, while the median rose 10.0 percent for white nonHispanic families; the two growth rates had been closer over the 1992-98 period. Although the mean did rise for both groups in the most recent three-year period, it rose much faster for the white non-Hispanic group (19.3 percent) than for the nonwhite or Hispanic group (11.2 percent).

Although median income for nonwhite or Hispanic families was essentially static from 1998 to 2001, the median income for African American families increased 20.3 percent in that period, from $\$ 21,200$ to $\$ 25,500$ (data not shown in tables). ${ }^{5}$ The mean for

5. CPS data for the same period show substantial but smaller growth in the median. The SCF data show a small decline in the median income of families with respondents who chose to identify themselves as Hispanic; this classification in the survey is not, as noted earlier, comparable to that used in the CPS. Median incomes of other minorities showed larger declines in the SCF, but the sample sizes of these groups are so small that none of these differences is statistically significant. 
1.-Continued

Thousands of 2001 dollars except as noted

\begin{tabular}{|c|c|c|c|c|c|c|c|c|}
\hline \multirow[b]{2}{*}{$\begin{array}{c}\text { Familv } \\
\text { characteristic }\end{array}$} & \multicolumn{4}{|c|}{1598} & \multicolumn{4}{|c|}{ 2)(11 } \\
\hline & Median & Mean & $\begin{array}{c}\text { Percentage } \\
\text { of } \\
\text { families } \\
\text { who saved }\end{array}$ & $\begin{array}{l}\text { Percentage } \\
\text { of } \\
\text { families }\end{array}$ & Median & Mean & $\begin{array}{l}\text { Percentage } \\
\text { of } \\
\text { families } \\
\text { who saved }\end{array}$ & $\begin{array}{l}\text { Percentage } \\
\text { of } \\
\text { families }\end{array}$ \\
\hline All families ..... & $\begin{array}{r}36.4 \\
(.9)\end{array}$ & $\begin{array}{l}\mathbf{5 7 . 9} \\
(1.2)\end{array}$ & 55.9 & 100.0 & $\begin{array}{r}39.9 \\
(.8)\end{array}$ & $\begin{array}{l}\mathbf{6 8 . 0} \\
(1.8)\end{array}$ & 59.2 & 100.0 \\
\hline 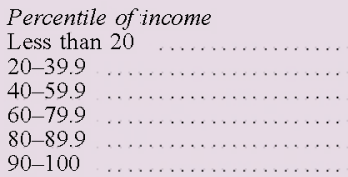 & $\begin{array}{r}9.0 \\
22.1 \\
36.4 \\
58.0 \\
86.0 \\
142.2\end{array}$ & $\begin{array}{r}8.6 \\
22.0 \\
37.0 \\
59.1 \\
86.6 \\
239.0\end{array}$ & $\begin{array}{l}32.1 \\
45.5 \\
56.1 \\
67.9 \\
73.7 \\
82.0\end{array}$ & $\begin{array}{l}20.0 \\
20.0 \\
20.0 \\
20.0 \\
10.0 \\
10.0\end{array}$ & $\begin{array}{r}10.3 \\
24.4 \\
39.9 \\
64.8 \\
98.7 \\
169.6\end{array}$ & $\begin{array}{r}10.0 \\
24.1 \\
40.3 \\
65.2 \\
98.0 \\
302.7\end{array}$ & $\begin{array}{l}30.0 \\
53.4 \\
61.3 \\
72.0 \\
74.9 \\
84.3\end{array}$ & $\begin{array}{l}20.0 \\
20.0 \\
20.0 \\
20.0 \\
10.0 \\
10.0\end{array}$ \\
\hline 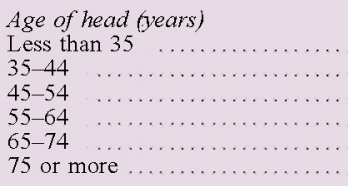 & $\begin{array}{l}29.8 \\
45.8 \\
55.2 \\
41.9 \\
26.5 \\
18.2\end{array}$ & $\begin{array}{l}39.3 \\
65.3 \\
76.0 \\
78.1 \\
50.9 \\
31.8\end{array}$ & $\begin{array}{l}53.0 \\
57.3 \\
57.8 \\
61.1 \\
56.3 \\
48.6\end{array}$ & $\begin{array}{l}23.3 \\
23.3 \\
19.2 \\
12.8 \\
11.2 \\
10.2\end{array}$ & $\begin{array}{l}33.4 \\
51.4 \\
54.5 \\
45.2 \\
27.8 \\
22.4\end{array}$ & $\begin{array}{l}44.2 \\
77.1 \\
93.2 \\
86.9 \\
58.1 \\
36.7\end{array}$ & $\begin{array}{l}52.9 \\
62.3 \\
61.7 \\
62.0 \\
61.8 \\
55.5\end{array}$ & $\begin{array}{l}22.7 \\
22.3 \\
20.6 \\
13.2 \\
10.7 \\
10.4\end{array}$ \\
\hline $\begin{array}{l}\text { Education of head } \\
\text { No high school diploma } \quad \ldots \ldots \ldots \\
\text { High school diploma } \quad \ldots \ldots \ldots \ldots \\
\text { Some college } \quad \ldots \ldots \ldots \ldots \ldots \ldots \\
\text { College degree } \quad \ldots \ldots \ldots \ldots \ldots \ldots\end{array}$ & $\begin{array}{l}16.9 \\
31.8 \\
38.6 \\
59.8\end{array}$ & $\begin{array}{l}23.6 \\
40.3 \\
55.3 \\
93.2\end{array}$ & $\begin{array}{l}39.5 \\
53.7 \\
56.7 \\
65.6\end{array}$ & $\begin{array}{l}16.5 \\
31.9 \\
18.5 \\
33.2\end{array}$ & $\begin{array}{l}17.0 \\
33.9 \\
40.9 \\
67.8\end{array}$ & $\begin{array}{r}25.1 \\
44.8 \\
55.5 \\
116.6\end{array}$ & $\begin{array}{l}38.7 \\
56.7 \\
61.7 \\
70.0\end{array}$ & $\begin{array}{l}16.0 \\
31.7 \\
18.3 \\
34.0\end{array}$ \\
\hline $\begin{array}{l}\text { Race or ethnicity of respondent } \\
\text { White non-Hispanic } \ldots \ldots \ldots \ldots \\
\text { Nonwhite or Hispanic } \quad \ldots \ldots \ldots \ldots\end{array}$ & $\begin{array}{l}41.1 \\
25.4\end{array}$ & $\begin{array}{l}64.1 \\
36.5\end{array}$ & $\begin{array}{l}59.8 \\
42.1\end{array}$ & $\begin{array}{l}77.7 \\
22.3\end{array}$ & $\begin{array}{l}45.2 \\
25.7\end{array}$ & $\begin{array}{l}76.5 \\
40.6\end{array}$ & $\begin{array}{l}62.9 \\
47.5\end{array}$ & $\begin{array}{l}76.2 \\
23.8\end{array}$ \\
\hline $\begin{array}{l}\text { Current work status of head } \\
\text { Working for someone else } \ldots \ldots \\
\text { Self-employed } \ldots \ldots \ldots \ldots \\
\text { Retired } \ldots \ldots \ldots \ldots \ldots \\
\text { Other not working } \ldots \ldots \ldots \ldots \ldots\end{array}$ & $\begin{array}{l}44.2 \\
57.4 \\
21.0 \\
12.7\end{array}$ & $\begin{array}{r}58.3 \\
119.1 \\
35.9 \\
23.9\end{array}$ & $\begin{array}{l}59.8 \\
61.1 \\
48.6 \\
33.7\end{array}$ & $\begin{array}{r}59.2 \\
11.3 \\
24.4 \\
5.1\end{array}$ & $\begin{array}{l}47.3 \\
63.3 \\
21.0 \\
16.7\end{array}$ & $\begin{array}{r}67.3 \\
138.3 \\
40.0 \\
36.4\end{array}$ & $\begin{array}{l}61.6 \\
70.4 \\
50.5 \\
42.7\end{array}$ & $\begin{array}{r}60.9 \\
11.7 \\
22.9 \\
4.5\end{array}$ \\
\hline $\begin{array}{l}\text { Region } \\
\text { Northeast } \ldots \ldots \ldots \ldots \ldots \ldots \ldots \\
\text { North Central } \ldots \ldots \ldots \ldots \ldots \ldots \\
\text { South } \ldots \ldots \ldots \ldots \ldots \ldots \ldots \ldots \ldots \ldots \\
\text { West } \ldots \ldots \ldots \ldots \ldots \ldots \ldots \ldots \ldots\end{array}$ & $\begin{array}{l}38.6 \\
35.8 \\
34.4 \\
39.4\end{array}$ & $\begin{array}{l}66.4 \\
53.3 \\
53.8 \\
62.1\end{array}$ & $\begin{array}{l}53.5 \\
58.3 \\
55.0 \\
56.9\end{array}$ & $\begin{array}{l}19.3 \\
23.6 \\
35.7 \\
21.3\end{array}$ & $\begin{array}{l}41.3 \\
43.9 \\
36.0 \\
40.7\end{array}$ & $\begin{array}{l}77.7 \\
64.7 \\
61.4 \\
74.0\end{array}$ & $\begin{array}{l}58.1 \\
63.0 \\
57.3 \\
59.5\end{array}$ & $\begin{array}{l}19.0 \\
23.0 \\
36.2 \\
21.8\end{array}$ \\
\hline $\begin{array}{l}\text { Housing status } \\
\text { Owner } \ldots \ldots \ldots \ldots \ldots \ldots \ldots \ldots \ldots \ldots \ldots \\
\text { Renter or other } \ldots \ldots \ldots \ldots \ldots \ldots\end{array}$ & $\begin{array}{l}47.6 \\
22.1\end{array}$ & $\begin{array}{l}72.6 \\
29.1\end{array}$ & $\begin{array}{l}62.2 \\
43.4\end{array}$ & $\begin{array}{l}66.2 \\
33.8\end{array}$ & $\begin{array}{l}52.1 \\
24.7\end{array}$ & $\begin{array}{l}85.1 \\
32.2\end{array}$ & $\begin{array}{l}66.7 \\
43.6\end{array}$ & $\begin{array}{l}67.7 \\
32.3\end{array}$ \\
\hline $\begin{array}{l}\text { Percentile of net worth } \\
\text { Less than } 25 \ldots \ldots \ldots \ldots \ldots \\
25-49.9 \ldots \ldots \ldots \ldots \ldots \ldots \ldots \ldots \\
50-74.9 \ldots \ldots \ldots \ldots \ldots \ldots \ldots \ldots \\
75-89.9 \ldots \ldots \ldots \ldots \ldots \ldots \ldots \ldots \\
90-100 \quad \ldots \ldots \ldots \ldots \ldots \ldots \ldots\end{array}$ & $\begin{array}{l}17.3 \\
33.1 \\
44.2 \\
61.8 \\
96.2\end{array}$ & $\begin{array}{r}22.1 \\
36.9 \\
51.0 \\
73.6 \\
193.7\end{array}$ & $\begin{array}{l}36.3 \\
50.2 \\
61.8 \\
71.9 \\
80.0\end{array}$ & $\begin{array}{l}25.0 \\
25.0 \\
25.0 \\
15.0 \\
10.0\end{array}$ & $\begin{array}{r}19.7 \\
34.9 \\
50.9 \\
70.0 \\
128.5\end{array}$ & $\begin{array}{r}24.0 \\
39.7 \\
58.4 \\
78.8 \\
256.4\end{array}$ & $\begin{array}{l}34.5 \\
54.3 \\
68.0 \\
77.7 \\
83.9\end{array}$ & $\begin{array}{l}25.0 \\
25.0 \\
25.0 \\
15.0 \\
10.0\end{array}$ \\
\hline
\end{tabular}

NoTE. For questions on income, respondents were asked to base their answers on the calendar year preceding the interview. For questions on saving, respondents were asked to base their answers on the year (that is, not specifically the calendar year) preceding the interview.

Percentage distributions may not sum to 100 because of rounding. Dollars have been converted to 2001 values with the current-methods consumer price

African American families rose 20.4 percent, from $\$ 31,400$ to $\$ 37,800$.

By work status, median income grew fastest between 1998 and 2001 for the self-employed (10.3 percent) and "other not working" (31.5 percent)." Although the latter group showed a large percentage increase, it continued to have the lowest median income of all the work-status groups. The median income of the retired group was unchanged, while the median income of families headed by work-

6. The "other not working" group consists of family heads who are unemployed and those who are out of the labor force but who are not retired or over age 65 . index for all urban consumers (see text box "The Data Used in This Article"). See the appendix for details on standard errors (shown in parentheses below the first row of data for the medians and means here and in table 3) and for definitions of family and family head.

ers who were not self-employed rose slightly. Mean income rose for all work-status groups between 1998 and 2001, but over the 1992-2001 period it rose most for the self-employed group (46.7 percent).

Over the 1998 to 2001 period, median income rose fastest in the North Central region. Growth in the mean was similar in all regions except the South, where it lagged slightly. Over the same period, the median and mean incomes of homeowners continued to pull away from the lower levels of other families. By net worth group, median and mean incomes grew for all over this period, but they rose most rapidly for the top decile of the distribution. 


\section{Family Saving}

Because saving out of current income is an important determinant of family net worth, the SCF asks respondents whether, over the preceding year, family spending was less than, more than, or about equal to, its income. Though only qualitative, the answers are a useful indicator of whether families are saving. 'Asking instead for a specific dollar amount would require much more time from respondents and would likely lower the rate of response to the survey.

Overall, the proportion of families who reported that they saved in the preceding year rose 3.3 percentage points, to 59.2 percent, the highest level since 1992, the year this measure was first recorded. The proportion of families that saved rose in all income groups except the bottom quintile, in all age groups except the youngest, in all education groups except the lowest, in all work-status groups (but particularly so in the self-employed group), in all regions, and in all wealth groups except the bottom quartile.

In contrast, estimates of the rate of saving by households as measured in the national income and product accounts (NIPA) were lower in 2001 than in the preceding three years, both in levels and as a percent of disposable income. However, the SCF and NIPA concepts of saving differ in some important ways. First, the underlying SCF question asks only whether family spending has been less, more, or about the same as its income over the past year. Thus, the amounts by which a family's expenditures differed from its income might have changed appreciably but without necessarily altering the family's answer.

Second, the NIPA measure of saving relies on definitions of income and consumption that may not be the same as those that respondents had in mind when answering the survey questions. For example, the NIPA measure of personal income includes payments employers make to their employees' definedbenefit pension plans but not the payments made from such plans to families, whereas the SCF measure includes only the latter. The SCF measure also includes realized capital gains, whereas the NIPA measure excludes capital gains of all forms, realized and unrealized.

The SCF also collects information on families' most important motivations for saving (table 2). ${ }^{7}$ Several patterns appear in the data. The fraction of families reporting retirement-related reasons-the

7. Although families were asked to report their motives for saving regardless of whether they were currently saving, some families reported only that they do not save. The analysis here is confined to the first reason reported by families.
2. Reasons respondents gave as most important for their families' saving, distributed by type of reason, 1992 , 1995, 1998, and 2001 surveys

Percent

\begin{tabular}{|c|c|c|c|c|}
\hline Reason & 1992 & 1995 & 1998 & 2001 \\
\hline Education & 9.1 & 10.8 & 11.0 & 10.9 \\
\hline For the family & 2.6 & 2.7 & 4.1 & 5.1 \\
\hline Buying own home & 4.0 & 5.1 & 4.4 & 4.2 \\
\hline Purchases & 9.7 & 12.8 & 9.7 & 9.5 \\
\hline Retirement & 19.4 & 23.7 & 33.0 & 32.1 \\
\hline Liquidity .. & 33.9 & 33.0 & 29.8 & 31.2 \\
\hline Investments & 7.6 & 4.2 & 2.0 & 1.0 \\
\hline No particular reason .... & 1.7 & .8 & 1.3 & 1.1 \\
\hline $\begin{array}{l}\text { When asked for a reason, } \\
\text { reported do not save } \\
\text { Total }\end{array}$ & $\begin{array}{l}12.0 \\
100\end{array}$ & $\begin{array}{c}6.8 \\
100\end{array}$ & $\begin{array}{r}4.9 \\
100\end{array}$ & $\begin{array}{r}4.9 \\
100\end{array}$ \\
\hline
\end{tabular}

Note. See note to table 1

most common response-declined slightly in 2001 after having increased consistently between 1992 and 1998. In contrast, the fraction reporting liquidityrelated reasons-the second most common response-increased in 2001. The proportion of families reporting education-related reasons held steady. Reported saving for investments continued to decline.

\section{NET WORTH}

From 1998 to 2001, net worth (wealth) - the difference between families' gross assets and their liabilities - rose strongly (table 3). Median wealth rose 10.4 percent from 1998 to 2001 and 40.5 percent from 1992 to 2001 . The mean rose 28.7 percent in the shorter period and 71.6 percent in the longer period.

By age group, median and mean net worth show a "hump" pattern that generally peaks in the 55-64 age group. This pattern reflects both life-cycle saving behavior and the lower expected total lifetime earnings of progressively older age groups. The median and mean values of wealth rise in tandem with income groups, a relationship reflecting both income earned from assets and a higher likelihood of saving among higher-income families. Wealth and income show similarly strong differentials across groups defined in terms of education, racial and ethnic background, occupation, and housing tenure (own or rent).

Sensitivity of Estimates to the Value of Equities

'Adjusting for the changes in the market valuation of assets-particularly corporate equities - that came

8. Liquidity-related reasons include "emergencies," the possibilities of unemployment and health care costs, and having ready money. 
after the survey would considerably alter the estimates of net worth discussed here. Although one cannot know what the survey families did and experienced after the interview, one can examine the sensitivity of the wealth estimates. We make the following assumptions to estimate a value of net worth for the survey families that reflects the subsequent decline in equity prices: The values of closely held businesses behave like equity prices, all equities and business assets change in value like an average portfolio of equities, no systematic portfolio rearrangements occurred since the time of the survey, and other assets held about steady in real terms.

We use the Wilshire 5000 index to adjust the values of equities and businesses from those reported at the date of each interview to a value as of October 4, 2002 (a 29.4 percent reduction from the same date in 2001). The adjustment reduces estimated median net worth to $\$ 80,700-$ a 6.3 percent decline relative to the value measured in the survey. The mean falls to $\$ 341,300$ - a 13.7 percent decline. Notably, even these adjusted values are above their 1998 levels. Because a disproportionate share of equities and other business assets is held by relatively wealthy families, the adjustment affects them disproportionately; relative to the measured values, wealth would fall 14.8 percent at the 95th percentile of the distribution of wealth, 11.9 percent at the 90th percentile, and 7.8 percent at the 75 th percentile.

3. Family net worth, by selected characteristics of families, 1992, 1995, 1998, and 2001 surveys Thousands of 2001 dollars

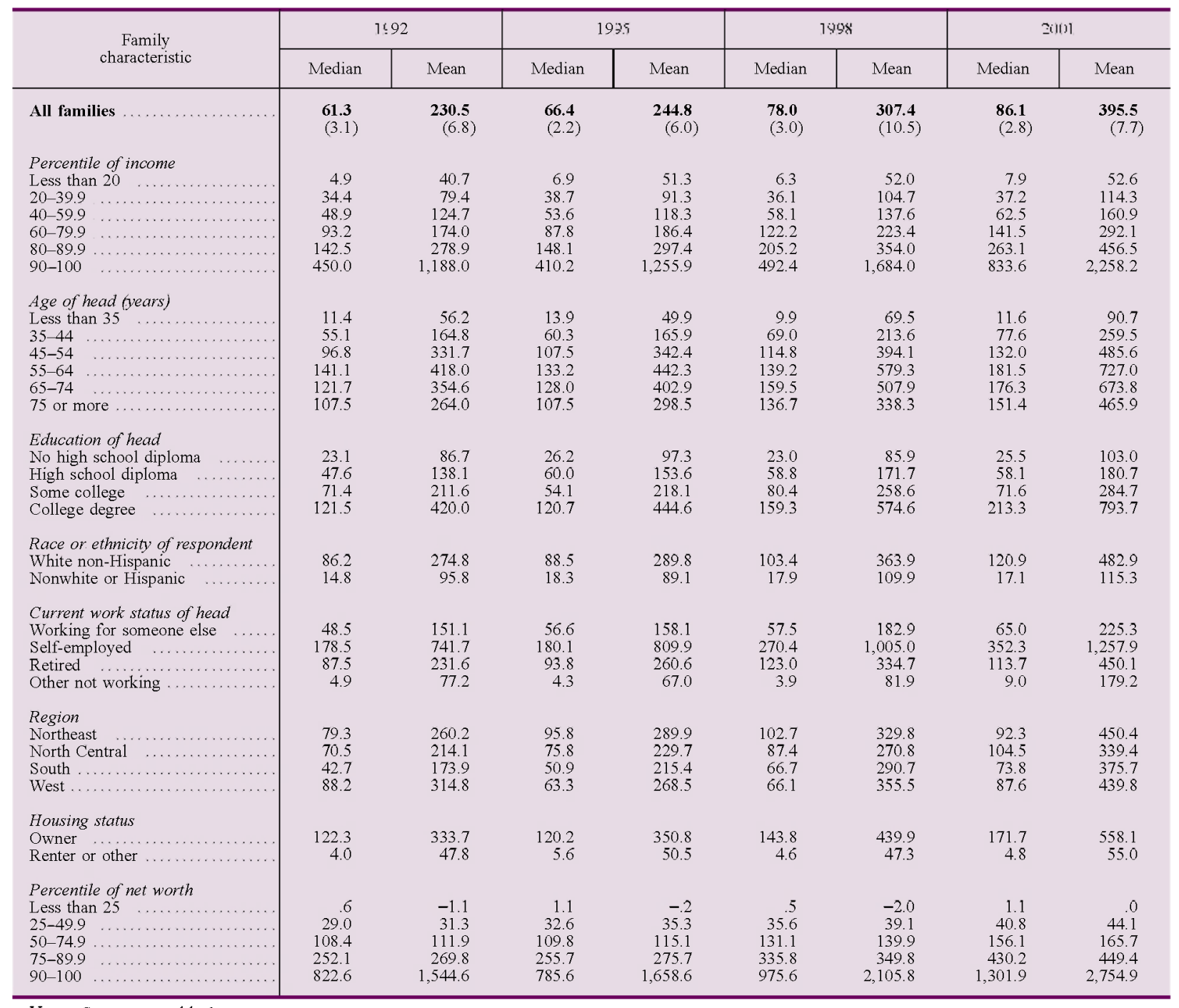

Note. See note to table 1 


\section{Net Worth by Demographic Category}

Between 1998 and 2001, the median and mean values of net worth grew for most demographic groups. Among wealth groups, the median net worth of the bottom quartile grew the most-120 percent-but from a 1998 base of only $\$ 500$. For the other wealth groups, the median grew at progressively higher rates ranging from 14.6 percent for the second quartile to 33.4 percent for the highest decile.

Net worth increased for all income groups, but particularly so for the top decile of the income distribution, in which the median rose 69.3 percent and the mean rose 34.1 percent. Over the 1992-2001 period, median and mean wealth rose the most for the top quintile; the increase in the mean in the top decile was especially large -90.1 percent.

Among age groups between 1998 and 2001, median wealth rose the most-30.4 percent-for the 55-64 group, which had experienced slower growth between 1992 and 1998 than the other age groups. Over the 1992-2001 period, median wealth grew the most - more than 40 percent - for the two oldest groups; the increase in the mean for these groups was also the largest during both the post-1992 and post1998 periods.

Across education groups, median net worth rose only for families headed by persons with less than a high school diploma or equivalent (10.9 percent) and for those headed by a person with a college degree (33.9 percent). Mean wealth rose for all education groups, but it rose notably-38.1 percent-only for the highest education group, which also gained disproportionately during the 1992-2001 period.

The growth in net worth among nonwhite and Hispanic families was markedly slower than that of other families in the 1998-2001 period. The median net worth of nonwhite and Hispanic families declined slightly, and the mean rose 4.9 percent; in contrast, the median net worth of other families rose 16.9 percent and the mean rose 32.7 percent. The subgroup of African Americans families did better than the overall minority group in the three-year period: Their median net worth rose 13.1 percent, from $\$ 16,800$ to $\$ 19,000$; the mean rose 8.3 percent, from $\$ 69,500$ to $\$ 75,700$ (not shown in tables).

The differences between all minority families and other families are even more striking for the 19922001 period: The median wealth of nonwhite and Hispanic families rose 15.5 percent and the mean rose 20.4 percent, while the median for other families increased 40.3 percent and the mean rose 75.7 percent. Some of the slower growth among nonwhite and Hispanic families appears to be a consequence of their relatively lower holdings of equities, which appreciated strongly over the period.

Across occupation groups, the self-employed received the largest dollar gains in the wealth measures over the 1998-2001 period; this result also holds over the 1992-2001 period. Over the three-year period, the percentage growth in these measures was highest for families headed by people who were neither working nor retired; nonetheless, wealth for this group remained quite small.

The median wealth of families living in the Northeast declined somewhat during the three-year period. At the same time, mean wealth in this region increased a bit faster than elsewhere. Over the nineyear period, the largest percentage growth for the typical family was seen in the South and the North Central regions.

By housing tenure, the growth of median and mean net worth was fastest for homeowners in both the three-year and nine-year periods. These differences largely reflect higher incomes of homeowners and generally rising real estate prices.

\section{ASSETS}

After having risen 9.1 percentage points over the six years from 1992 to 1998 , the share of financial assets in families' total assets rose 1.3 percentage points in the three years between 1998 and 2001 (table 4); the slowdown reflects complex changes in ownership and holdings of more specific types of financial assets (table 5) - particularly the growth in assets backed by publicly traded equities (table 6). By definition, the rise in the share of financial assets in total assets is exactly offset by the decline in the share of nonfinancial assets (tables 7 and 8).

The percent of families having any type of asset in 2001, 96.7 percent, was virtually unchanged from 1998 (table 8); this leveling off follows a period of growth since at least 1992. Between 1998 and 2001, the median holding of those with assets increased 9.8 percent, about the same rate of growth seen since 1992. Across most of the demographic groups shown in table 8, percentage ownership of any type of asset was steady at or near 100 percent but declined by more than 1 percentage point for the families with incomes in the lowest 20 percent of the distribution, those headed by persons younger than 35 or between the ages of 65 and 74, and those headed by persons who were neither retired nor working. The median holding of assets among families having any assets rose for nearly every group; exceptions were small declines for families with incomes in the 40th to 
60th percentiles of the distribution of income and households headed by retired persons.

\section{Financial Assets}

After showing declines in earlier surveys, the share of transaction accounts in total assets held about steady between 1998 and 2001 (table 4). The share of another important type of deposit, certificates of deposit, continued its longer-term pattern of decline. The shares of formal retirement accounts and of "other managed assets" both increased notably from 1998 to 2001.

Overall ownership of any financial asset rose only slightly from 1998 to 2001 after showing steady increases in the past several surveys (table 5). The median holding increased 14.3 percent between the two most recent surveys, only a small part of the 97.2 percent increase since 1992. Across demographic groups, there were marked changes in ownership only for a few groups; ownership declined at least 1 percentage point for families headed by persons aged 65 to 74 and families headed by retired persons. Median holdings of financial assets went up or were unchanged for most groups; the only notable decline was among households headed by retired persons.

\section{Transaction Accounts and Certificates of Deposit}

In 2001, 90.9 percent of families had some type of transaction account - a category comprising checking, savings, and money market deposit accounts,

4. Value of financial assets of all families, distributed by type of asset, 1992, 1995, 1998, and 2001 surveys Percent

\begin{tabular}{|c|c|c|c|c|}
\hline $\begin{array}{c}\text { Type of financial } \\
\text { asset }\end{array}$ & 1992 & 1995 & 1998 & 2001 \\
\hline Transaction accounts & 17.5 & 13.9 & 11.4 & 11.5 \\
\hline Certificates of deposit & 8.0 & 5.6 & 4.3 & 3.1 \\
\hline Savings bonds & 1.1 & 1.3 & .7 & .7 \\
\hline Bonds $\ldots \ldots \ldots \ldots \ldots$ & 8.4 & 6.3 & 4.3 & 4.6 \\
\hline Stocks ..... & 16.5 & 15.6 & 22.7 & 21.6 \\
\hline Mutual funds (excluding & & & & \\
\hline money market funds) & 7.6 & 12.7 & 12.4 & 12.2 \\
\hline Retirement accounts ..... & 25.7 & 28.1 & 27.6 & 28.4 \\
\hline Cash value of life insurance & 5.9 & 7.2 & 6.4 & 5.3 \\
\hline Other managed assets $\ldots$. & 5.4 & 5.9 & 8.6 & 10.6 \\
\hline Other & 3.8 & 3.3 & 1.7 & 1.9 \\
\hline Total & 100 & 100 & 100 & 100 \\
\hline Memo. & & & & \\
\hline $\begin{array}{l}\text { Financial assets as a } \\
\text { share of total assets }\end{array}$ & 31.6 & 36.7 & 40.7 & 42.0 \\
\hline
\end{tabular}

NotE. For this and following tables, see text for definition of asset categories. Also see note to table 1 . money market mutual funds, and call accounts at brokerages. This ownership rate is only ; 2 percentage point higher than in the preceding survey, but it is 4.0 percentage points higher than the level in 1992. Families that did not have transaction accounts in 2001 were disproportionately likely to have low incomes, to be younger than 35 , to be nonwhite or Hispanic, to be headed by a person who was neither working nor retired, to be a renter, and to have relatively low levels of wealth (see box "Families without a Checking Account"); however, the rate of ownership rose at least slightly for all of these groups between 1998 and 2001.

Median holdings of transaction accounts rose 21.2 percent from 1998 to 2001. Across the demographic groups shown, median holdings rose or were unchanged for almost every group. The rate of increase was particularly pronounced for families headed by persons aged 55-74 and families in the highest income and wealth groups.

Certificates of deposit (CDs), interest-bearing deposits with a set term, are traditionally viewed as a low-risk saving vehicle, one often used by people who desire a safe haven from the volatility of financial markets. The fraction of families owning CDs continued the slow increase observed since 1995; it edged up to 15.7 percent in 2001. Ownership rose most notably for families with incomes in the top decile of the distribution and for families headed by self-employed persons; ownership declined notably for the pre-retirement, 55-64 age group. The overall median value of CD holdings fell 8.0 percent over the 1998-2001 period, and the decline was shared by most demographic groups; notable exceptions were the top decile of the income distribution, families headed by persons younger than 35, nonwhite or Hispanic families, and families headed by persons who were neither working nor retired.

\section{Savings Bonds and Other Bonds}

Savings bonds are owned disproportionately by families headed by persons between 35 and 64 years of age, by families with incomes in the highest 40 percent of the distribution, and by families in the top half of the distribution of net worth. From 1998 to 2001, the overall share of families owning savings bonds declined 2.6 percentage points, to 16.7 percent; from 1992 to 2001 , it declined 5.6 percentage points. The median holding fell slightly over the three-year period, to $\$ 1,000$, and that decline was shared by most groups. 


\section{Families without a Checking Account}

Between 1998 and 2001, the proportion of families with any type of: transaction account rose $1 / 2$ percentage point (table 5), and the share without a checking account fell the same amount, from 13.2 percent to 12.7 percent (not shown in tables). The decline in the fraction of families without a checking account follows a longer trend; in 1992, 16.6 percent of families lacked such an account.'

Among families without a checking account in 2001, 50.4 percent had held such an account in the past. Among families without a checking account, 59.3 percent had incomes in the lowest 20 percent of that distribution, 55.8 percent were headed by persons younger than 45 , and 57.4 percent were nonwhite or Hispanic.

The SCF asked all families that did not have a checking account to give a reason for not having an account (table). The most commonly reported reason-given by 28.6 percent of families - was that the family did not write enough checks to make account ownership worthwhile. Another 14.0 percent said that they did not have enough money to make account ownership worthwhile. And 22.6 percent said that they did not like dealing with banks; this response showed the largest increase since $1998-4.1$ percentage points.

1. For the definition of transaction account, see the main text. For a discussion of the ways that lower-income families obtain checking and credit services and the effects that developments in electronic transactions may have on such families, see Jeanne $M$. Hogarth and Kevin $\mathrm{H}$. O'Donnell, "Banking Relationships of Lower-Income Families and the Governmental Trend toward Electronic Payments," Federal Reserve Bulletin, vol. 85 (July 1999), pp. 459-73.
When attention is further restricted to families that once had a checking account (not shown in tables), some substantively different patterns emerge. The proportion of such families reporting that they do not like banks declined to 18.2 percent in 2001 . This decline is offset by an increase in the proportion reporting that they could not manage a checking account and an increase in the proportion giving more strictly "economic" reasons- 12.8 percent said that service charges were too high, and 6.3 percent said that they had some sort of credit problem.

Distribution of reasons cited by respondents for their families? not having a checking account, by reason, 1992, 1995, 1998, and 2001 surveys

Percent

\begin{tabular}{|c|c|c|c|c|}
\hline Reason & 1992 & 1995 & 1998 & 2001 \\
\hline 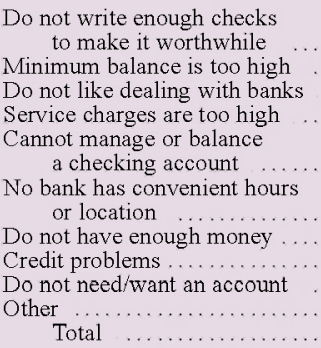 & $\begin{array}{r}30.4 \\
8.7 \\
15.3 \\
11.3 \\
6.5 \\
\\
.8 \\
21.2 \\
.7 \\
3.2 \\
11.9 \\
100\end{array}$ & $\begin{array}{r}25.3 \\
8.8 \\
18.6 \\
8.4 \\
8.0 \\
1.2 \\
20.0 \\
1.4 \\
4.9 \\
3.5 \\
100\end{array}$ & $\begin{array}{r}28.4 \\
8.6 \\
18.5 \\
11.0 \\
7.2 \\
1.2 \\
12.9 \\
2.7 \\
6.3 \\
3.1 \\
100\end{array}$ & $\begin{array}{r}28.6 \\
6.5 \\
22.6 \\
10.2 \\
6.6 \\
4 \\
4 \\
14.0 \\
3.6 \\
5.3 \\
2.1 \\
100\end{array}$ \\
\hline
\end{tabular}

Other types of bonds were held by only 3.0 percent of families over the three-year period. As measured in the survey, the ownership rate had been declining steadily before then-it was 5.7 percent in 1989 . Ownership is notably more likely among families in the highest income and wealth groups. The median value of holdings fell 10.9 percent over the three-year period. But a steady rise in the mean (not shown in tables) in the 1989-98 period of declining ownership rates suggests that these bonds remain an important part of the financial assets of some relatively wealthy families.

9. Other bonds as reported in the survey are held directly and include corporate and mortgage-backed bonds; federal, state, and local government bonds; and foreign bonds. In the survey, financial assets held indirectly are those held in mutual funds, in retirement accounts, and in other managed assets.

\section{Publicly Traded Stock}

The direct ownership of publicly traded stocks is more widespread than the direct ownership of bonds, but it is also concentrated among high-income and high-wealth families. The fraction of families with such stock holdings has been rising since 1995; it rose 2.1 percentage points over the most recent threeyear period, to 21.3 percent. Ownership went up for almost every group; exceptions were families with incomes in the 40th to 60th percentiles of the distribution and families headed by persons aged 45 to 54 or 65 to 74 . Increases in ownership were most notable for families at the top of the income and wealth distributions, and they were spread roughly equally over racial and ethnic groups.

Despite the decline of major stock price indexes in 2001 to about the levels of 1998 , the median value of stock holdings increased 5.3 percent over that threeyear period. Across demographic groups, the changes in medians were mixed. However, the median 
increased notably for families headed by persons aged 55 and older and for families with net worth in the highest 10 percent of the distribution. The median increased substantially among families living in the Northeast (not shown in tables); the median grew more slowly or declined in other areas.

\section{Mutual Funds}

The pattern of ownership of mutual funds (which, in this article, are those held directly and exclude money market funds) is very similar to that of stocks. In a continuation of earlier trends, the fraction of families owning mutual funds rose 1.2 percentage points over the 1998-2001 period, to 17.7 percent. Over this period, the percent of families with stock funds and taxable funds of government-backed bonds rose, while the ownership of tax-exempt bond funds, other bond funds, and combination funds fell. The rise in ownership of mutual funds of any type was spread across all income groups, but it was particularly steep in the highest decile. The patterns were somewhat mixed across other groups; the increases were large for families headed by persons aged 55 and older. The rate of ownership rose for white non-Hispanic families, and it fell for other families.

Between 1998 and 2001, the median value of mutual fund holdings for families with such funds grew 28.7 percent, a somewhat faster pace than that over the preceding two surveys. The most notable increases were for families with incomes in the highest decile, families headed by self-employed workers, homeowners, and families with wealth in the lowest quartile or the highest decile. Median holdings also grew substantially for nonwhite or Hispanic families but from a much lower base than was the case for other families.

\section{Retirement Accounts}

Ownership of tax-deferred retirement accounts increases with both income and net worth. ${ }^{10}$ Owner-

10. The tax-deferred retirement accounts consist of IRAs, Keogh accounts, and certain employer-sponsored accounts. Employersponsored accounts include 401(k), 403(b), and thrift saving accounts from current or past jobs; other current job plans from which loans or withdrawals can be made; and accounts from past jobs from which the family expects to receive the account balance in the future. This definition of employer-sponsored plans is intended to confine the analysis to amounts that are portable across jobs and to which families will ultimately have full access.

IRAs and Keoghs may be invested in virtually any asset, including stocks, bonds, mutual funds, options, and real estate. In principle, employer-sponsored plans may be similarly broadly invested; in ship is also more likely among families headed by persons less than 65 years of age. The older group is less likely to have such accounts for several reasons. First, even though retirement accounts have been in existence for about twenty years, they may not have become common until relatively late in the careers of people in the group. Second, once a person reaches age $59 \% 2$, funds in retirement accounts may be withdrawn without penalty, and some in the group may have done so. Third, families may have used funds from retirement accounts accumulated from previous employment to purchase an annuity at retirement; annuities are treated in this article as a separate type of managed asset.

From 1998 to 2001, the fraction of families with retirement accounts rose 3.3 percentage points, to 52.2 percent. In $2001,20.9$ percent had only an employer-provided account of the types included here, 18.4 percent had only an IRA or Keogh account, and 12.9 percent had both (not shown in tables). Among these three groups, growth was slowest for the first group. Ownership of any type of retirement account was up in almost every demographic group.

The median holding of tax-deferred retirement assets rose 11.1 percent over the recent three-year period; although this rate is notably lower than the nearly 33 percent rate of growth registered between 1995 and 1998, it is more in line with earlier trends. In the 1998 to 2001 period, growth in the median was particularly marked for families with incomes in the highest 40 percent of the distribution and families with net worth in the highest quarter of that distribution.

Families may accumulate a variety of assets and income entitlements to support their retirement. As noted earlier, the most common set of reasons survey respondents gave for saving was retirement related. Thus, many of the assets described under categories other than retirement accounts are likely to be an important part of the retirement saving plan for families.

At least two common types of retirement plan are not included in the assets described in this section: social security (the federally funded Old-Age and Survivors' Insurance program, or OASI) and employer-sponsored defined-benefit plans. OASI is well described elsewhere, and it covers the great majority of the population. ${ }^{11}$ The retirement income provided by defined-benefit plans is typically based

practice, individuals' choices for investment are often restricted to a narrower set offered by their employers.

11. For a detailed description of OASI, see Social Security Administration, "Online Social Security Handbook," Publication 65-008, www.ssa.gov/OP_Home/handbook/ssa-hbk.htm. 
5. Family holdings of financial assets, by selected characteristics of families and type of asset, 1998 and 2001 surveys A. 1998 Survey of Consumer Finances

\begin{tabular}{|c|c|c|c|c|c|c|c|c|c|c|c|}
\hline $\begin{array}{c}\text { Familv } \\
\text { characteristic }\end{array}$ & $\begin{array}{l}\text { Trans- } \\
\text { action } \\
\text { accounts }\end{array}$ & $\begin{array}{l}\text { Certifi- } \\
\text { cates of } \\
\text { deposit }\end{array}$ & $\begin{array}{l}\text { Savings } \\
\text { bonds }\end{array}$ & Bonds & Stocks & $\begin{array}{l}\text { Mutual } \\
\text { funds }\end{array}$ & $\begin{array}{c}\text { Retire- } \\
\text { ment } \\
\text { accounts }\end{array}$ & $\begin{array}{c}\text { Life } \\
\text { insurance }\end{array}$ & $\begin{array}{c}\text { Other } \\
\text { managed } \\
\text { assets }\end{array}$ & Other & $\begin{array}{l}\text { Any } \\
\text { financial } \\
\text { asset }\end{array}$ \\
\hline & \multicolumn{11}{|c|}{ F'ereentage of families holting asset } \\
\hline All families & 90.5 & 15.3 & 19.3 & 3.0 & 19.2 & 16.5 & 48.9 & 29.6 & 5.9 & 9.4 & 92.9 \\
\hline 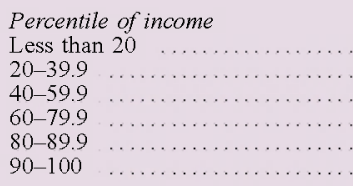 & $\begin{array}{l}68.5 \\
90.3 \\
95.1 \\
98.8 \\
99.6 \\
99.7\end{array}$ & $\begin{array}{l}12.1 \\
15.6 \\
15.4 \\
15.2 \\
17.9 \\
18.5\end{array}$ & $\begin{array}{r}4.9 \\
12.2 \\
19.6 \\
25.8 \\
35.4 \\
32.9\end{array}$ & $\begin{array}{r}* \\
* \\
2.7 \\
2.9 \\
3.2 \\
10.8\end{array}$ & $\begin{array}{r}3.7 \\
9.7 \\
17.9 \\
21.5 \\
32.7 \\
53.6\end{array}$ & $\begin{array}{r}3.2 \\
8.7 \\
13.8 \\
20.2 \\
28.8 \\
44.3\end{array}$ & $\begin{array}{r}9.4 \\
30.9 \\
53.5 \\
69.2 \\
75.3 \\
87.5\end{array}$ & $\begin{array}{l}16.6 \\
22.2 \\
27.7 \\
34.7 \\
44.3 \\
49.0\end{array}$ & $\begin{array}{r}3.0 \\
4.5 \\
4.0 \\
7.1 \\
7.2 \\
14.9\end{array}$ & $\begin{array}{r}8.3 \\
8.0 \\
10.5 \\
9.9 \\
8.7 \\
11.5\end{array}$ & $\begin{array}{r}75.6 \\
93.0 \\
97.1 \\
99.1 \\
99.8 \\
100.0\end{array}$ \\
\hline 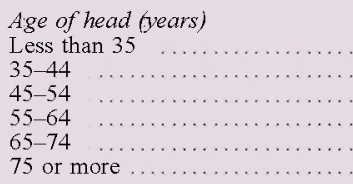 & $\begin{array}{l}84.6 \\
90.5 \\
93.5 \\
93.9 \\
94.1 \\
89.7\end{array}$ & $\begin{array}{r}6.2 \\
9.4 \\
11.8 \\
18.6 \\
29.9 \\
35.9\end{array}$ & $\begin{array}{l}17.2 \\
24.9 \\
21.8 \\
18.1 \\
16.1 \\
12.0\end{array}$ & $\begin{array}{l}1.0 \\
1.5 \\
2.8 \\
3.5 \\
7.2 \\
5.9\end{array}$ & $\begin{array}{l}13.1 \\
18.9 \\
22.6 \\
25.0 \\
21.1 \\
18.0\end{array}$ & $\begin{array}{l}12.2 \\
16.0 \\
23.0 \\
15.2 \\
18.0 \\
15.1\end{array}$ & $\begin{array}{l}39.8 \\
59.6 \\
59.2 \\
58.4 \\
46.1 \\
16.7\end{array}$ & $\begin{array}{l}18.0 \\
29.0 \\
32.9 \\
35.8 \\
39.1 \\
32.6\end{array}$ & $\begin{array}{r}1.9 \\
3.9 \\
6.5 \\
6.5 \\
11.8 \\
11.6\end{array}$ & $\begin{array}{r}10.1 \\
11.8 \\
9.1 \\
8.4 \\
7.3 \\
6.4\end{array}$ & $\begin{array}{l}88.6 \\
93.3 \\
94.9 \\
95.6 \\
95.6 \\
92.1\end{array}$ \\
\hline $\begin{array}{l}\text { Race or ethnicity of respondent } \\
\text { White non-Hispanic } \\
\text { Nonwhite or Hispanic } \\
\text { No.......... }\end{array}$ & $\begin{array}{l}94.7 \\
75.8\end{array}$ & $\begin{array}{r}17.9 \\
6.4\end{array}$ & $\begin{array}{r}22.2 \\
9.2\end{array}$ & $\begin{array}{r}3.7 \\
.4\end{array}$ & $\begin{array}{r}22.1 \\
9.1\end{array}$ & $\begin{array}{r}18.8 \\
8.4\end{array}$ & $\begin{array}{l}53.7 \\
32.1\end{array}$ & $\begin{array}{l}32.1 \\
20.8\end{array}$ & $\begin{array}{l}7.1 \\
1.7\end{array}$ & $\begin{array}{l}9.7 \\
8.3\end{array}$ & $\begin{array}{l}96.3 \\
81.2\end{array}$ \\
\hline $\begin{array}{l}\text { Current work status of head } \\
\text { Working for someone else } \ldots \ldots \\
\text { Self-employed } \ldots \ldots \ldots \ldots \ldots \ldots \\
\text { Retired } \ldots \ldots \ldots \ldots \ldots \ldots \ldots \ldots \\
\text { Other not working } \ldots \ldots \ldots \ldots \ldots \ldots\end{array}$ & $\begin{array}{l}92.7 \\
95.4 \\
87.2 \\
69.1\end{array}$ & $\begin{array}{r}11.1 \\
11.7 \\
28.8 \\
7.6\end{array}$ & $\begin{array}{l}21.8 \\
20.2 \\
14.4 \\
11.8\end{array}$ & $\begin{array}{l}1.9 \\
5.4 \\
5.1 \\
*\end{array}$ & $\begin{array}{r}19.5 \\
26.5 \\
17.1 \\
8.8\end{array}$ & $\begin{array}{r}16.6 \\
24.8 \\
14.8 \\
4.8\end{array}$ & $\begin{array}{l}58.9 \\
53.5 \\
28.8 \\
17.5\end{array}$ & $\begin{array}{l}27.5 \\
39.5 \\
32.4 \\
17.6\end{array}$ & $\begin{array}{l}4.2 \\
8.7 \\
9.9 \\
*\end{array}$ & $\begin{array}{r}9.4 \\
14.1 \\
6.8 \\
10.9\end{array}$ & $\begin{array}{l}94.8 \\
96.9 \\
90.3 \\
75.2\end{array}$ \\
\hline $\begin{array}{l}\text { Housing status } \\
\text { Owner } \ldots \ldots \ldots \ldots \ldots \ldots \ldots \ldots \ldots \ldots \ldots \ldots \ldots \\
\text { Renter or other } \ldots \ldots \ldots \ldots \ldots \ldots\end{array}$ & $\begin{array}{l}96.2 \\
79.2\end{array}$ & $\begin{array}{r}18.9 \\
8.3\end{array}$ & $\begin{array}{l}23.3 \\
11.5\end{array}$ & $\begin{array}{l}3.8 \\
1.3\end{array}$ & $\begin{array}{r}24.9 \\
8.0\end{array}$ & $\begin{array}{r}21.0 \\
7.5\end{array}$ & $\begin{array}{l}58.4 \\
30.2\end{array}$ & $\begin{array}{l}36.9 \\
15.2\end{array}$ & $\begin{array}{l}7.7 \\
2.4\end{array}$ & $\begin{array}{r}8.7 \\
10.8\end{array}$ & $\begin{array}{l}97.5 \\
84.1\end{array}$ \\
\hline 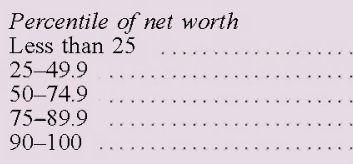 & $\begin{array}{r}72.1 \\
91.4 \\
98.5 \\
99.7 \\
100.0\end{array}$ & $\begin{array}{r}3.0 \\
9.8 \\
19.6 \\
30.2 \\
26.8\end{array}$ & $\begin{array}{r}7.0 \\
16.3 \\
24.1 \\
27.8 \\
33.2\end{array}$ & $\begin{array}{r}* \\
* \\
2.2 \\
3.4 \\
16.9\end{array}$ & $\begin{array}{r}3.2 \\
9.4 \\
18.8 \\
36.4 \\
58.7\end{array}$ & $\begin{array}{r}2.1 \\
8.7 \\
15.3 \\
35.5 \\
46.4\end{array}$ & $\begin{array}{l}18.5 \\
44.3 \\
56.4 \\
72.0 \\
83.0\end{array}$ & $\begin{array}{l}10.7 \\
23.8 \\
35.6 \\
45.5 \\
52.2\end{array}$ & $\begin{array}{r}* \\
2.4 \\
5.9 \\
10.2 \\
22.1\end{array}$ & $\begin{array}{r}7.9 \\
10.0 \\
8.2 \\
10.2 \\
13.1\end{array}$ & $\begin{array}{r}78.0 \\
94.8 \\
99.1 \\
99.9 \\
100.0\end{array}$ \\
\hline & \multicolumn{11}{|c|}{ 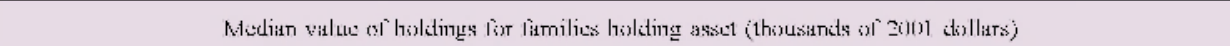 } \\
\hline All families & 3.3 & 16.3 & 1.1 & 48.8 & 19.0 & 27.2 & 26.1 & 7.9 & 34.3 & 3.3 & 24.5 \\
\hline 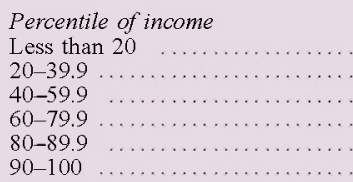 & $\begin{array}{r}.8 \\
1.6 \\
2.5 \\
4.7 \\
8.2 \\
19.6\end{array}$ & $\begin{array}{l}10.9 \\
21.8 \\
15.2 \\
15.8 \\
17.4 \\
21.8\end{array}$ & $\begin{array}{r}1.4 \\
1.1 \\
.5 \\
.8 \\
1.5 \\
1.1\end{array}$ & $\begin{array}{r}* \\
* \\
23.0 \\
20.6 \\
20.7 \\
117.6\end{array}$ & $\begin{array}{r}16.3 \\
10.9 \\
8.2 \\
16.3 \\
19.6 \\
54.4\end{array}$ & $\begin{array}{l}21.8 \\
27.2 \\
10.9 \\
19.6 \\
21.8 \\
65.3\end{array}$ & $\begin{array}{r}6.5 \\
9.8 \\
13.1 \\
22.9 \\
47.1 \\
98.0\end{array}$ & $\begin{array}{r}4.4 \\
5.4 \\
4.6 \\
8.2 \\
10.9 \\
19.6\end{array}$ & $\begin{array}{l}17.4 \\
27.8 \\
25.5 \\
32.9 \\
27.2 \\
98.0\end{array}$ & $\begin{array}{r}.7 \\
1.4 \\
2.7 \\
5.4 \\
6.2 \\
27.2\end{array}$ & $\begin{array}{r}2.0 \\
7.1 \\
17.6 \\
39.8 \\
87.6 \\
241.1\end{array}$ \\
\hline 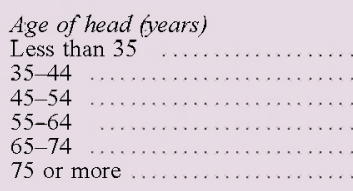 & $\begin{array}{l}1.6 \\
3.1 \\
4.9 \\
4.4 \\
6.1 \\
6.7\end{array}$ & $\begin{array}{r}2.7 \\
8.7 \\
12.5 \\
18.5 \\
21.8 \\
32.7\end{array}$ & $\begin{array}{r}.5 \\
.8 \\
1.1 \\
1.6 \\
2.2 \\
5.4\end{array}$ & $\begin{array}{r}3.3 \\
60.2 \\
34.5 \\
108.8 \\
56.6 \\
20.5\end{array}$ & $\begin{array}{r}5.4 \\
13.1 \\
26.1 \\
22.9 \\
54.4 \\
54.4\end{array}$ & $\begin{array}{r}7.6 \\
15.2 \\
32.7 \\
63.1 \\
65.3 \\
64.2\end{array}$ & $\begin{array}{r}7.6 \\
22.3 \\
37.0 \\
50.9 \\
41.4 \\
32.7\end{array}$ & $\begin{array}{r}2.9 \\
9.3 \\
10.9 \\
10.3 \\
9.3 \\
5.4\end{array}$ & $\begin{array}{l}21.2 \\
27.2 \\
42.8 \\
70.8 \\
45.0 \\
32.7\end{array}$ & $\begin{array}{r}1.1 \\
2.7 \\
6.5 \\
10.9 \\
6.5 \\
8.9\end{array}$ & $\begin{array}{r}5.0 \\
24.9 \\
41.1 \\
49.6 \\
49.9 \\
39.9\end{array}$ \\
\hline $\begin{array}{l}\text { Race or ethnicity of respondent } \\
\text { White non-Hispanic } \quad \ldots \ldots \ldots \ldots \\
\text { Nonwhite or Hispanic } \quad \ldots \ldots \ldots \ldots\end{array}$ & $\begin{array}{l}4.0 \\
1.6\end{array}$ & $\begin{array}{r}18.5 \\
6.8\end{array}$ & $\begin{array}{r}1.1 \\
.8\end{array}$ & $\begin{array}{l}50.1 \\
15.4\end{array}$ & $\begin{array}{r}21.8 \\
9.8\end{array}$ & $\begin{array}{l}31.6 \\
10.9\end{array}$ & $\begin{array}{l}28.3 \\
14.2\end{array}$ & $\begin{array}{l}8.2 \\
5.4\end{array}$ & $\begin{array}{l}34.8 \\
25.1\end{array}$ & $\begin{array}{l}4.4 \\
1.1\end{array}$ & $\begin{array}{r}32.7 \\
7.1\end{array}$ \\
\hline $\begin{array}{l}\text { Current work status of head } \\
\text { Working for someone else } \ldots \ldots \\
\text { Self-employed } \ldots \ldots \ldots \ldots \ldots \ldots \\
\text { Retired } \ldots \ldots \ldots \ldots \ldots \ldots \ldots \ldots \\
\text { Other not working } \ldots \ldots \ldots \ldots \ldots \ldots \ldots\end{array}$ & $\begin{array}{l}2.9 \\
6.9 \\
5.4 \\
1.1\end{array}$ & $\begin{array}{r}9.8 \\
23.9 \\
26.1 \\
10.9\end{array}$ & $\begin{array}{r}.7 \\
1.0 \\
2.7 \\
.9\end{array}$ & $\begin{array}{r}16.3 \\
163.3 \\
54.4 \\
*\end{array}$ & $\begin{array}{l}10.9 \\
56.6 \\
54.4 \\
12.0\end{array}$ & $\begin{array}{l}17.4 \\
43.5 \\
59.9 \\
19.0\end{array}$ & $\begin{array}{l}21.8 \\
53.9 \\
33.7 \\
16.3\end{array}$ & $\begin{array}{r}7.6 \\
12.5 \\
6.5 \\
5.4\end{array}$ & $\begin{array}{l}32.7 \\
42.8 \\
34.8 \\
*\end{array}$ & $\begin{array}{r}2.0 \\
7.6 \\
7.6 \\
.5\end{array}$ & $\begin{array}{r}20.8 \\
49.0 \\
35.7 \\
2.7\end{array}$ \\
\hline $\begin{array}{l}\text { Housing status } \\
\text { Owner } \ldots \ldots \ldots \ldots \ldots \ldots \ldots \ldots \ldots \ldots \ldots \ldots \\
\text { Renter or other } \ldots \ldots \ldots \ldots \ldots \ldots \ldots\end{array}$ & $\begin{array}{l}5.4 \\
1.2\end{array}$ & $\begin{array}{l}19.6 \\
10.9\end{array}$ & $\begin{array}{r}1.1 \\
.7\end{array}$ & $\begin{array}{l}45.2 \\
54.4\end{array}$ & $\begin{array}{r}21.8 \\
8.7\end{array}$ & $\begin{array}{l}32.7 \\
13.1\end{array}$ & $\begin{array}{r}32.7 \\
8.5\end{array}$ & $\begin{array}{l}8.7 \\
5.4\end{array}$ & $\begin{array}{l}34.8 \\
25.1\end{array}$ & $\begin{array}{l}5.4 \\
1.1\end{array}$ & $\begin{array}{r}44.9 \\
3.8\end{array}$ \\
\hline 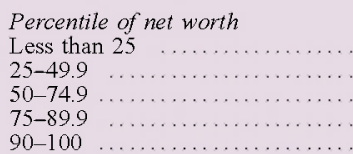 & $\begin{array}{r}.7 \\
1.9 \\
5.2 \\
11.4 \\
25.0\end{array}$ & $\begin{array}{r}1.6 \\
6.7 \\
16.3 \\
27.2 \\
47.9\end{array}$ & $\begin{array}{r}.4 \\
.5 \\
1.1 \\
2.2 \\
2.2\end{array}$ & $\begin{array}{r}* \\
* \\
10.9 \\
27.2 \\
108.8\end{array}$ & $\begin{array}{r}.8 \\
3.3 \\
8.7 \\
28.6 \\
92.5\end{array}$ & $\begin{array}{r}1.6 \\
6.5 \\
15.2 \\
38.4 \\
116.5\end{array}$ & $\begin{array}{r}2.3 \\
9.0 \\
30.5 \\
64.8 \\
136.1\end{array}$ & $\begin{array}{r}1.3 \\
5.4 \\
7.6 \\
10.9 \\
21.8\end{array}$ & $\begin{array}{r}* \\
10.9 \\
21.8 \\
25.5 \\
130.6\end{array}$ & $\begin{array}{r}.5 \\
2.0 \\
6.5 \\
7.6 \\
21.8\end{array}$ & $\begin{array}{r}1.1 \\
11.4 \\
46.8 \\
157.2 \\
500.1\end{array}$ \\
\hline
\end{tabular}


5. Continued

B. 2001 Survey of Consumer Finances

\begin{tabular}{|c|c|c|c|c|c|c|c|c|c|c|c|}
\hline $\begin{array}{c}\text { Family } \\
\text { characteristic }\end{array}$ & $\begin{array}{l}\text { Trans- } \\
\text { action } \\
\text { accounts }\end{array}$ & $\begin{array}{l}\text { Certifi- } \\
\text { cates of } \\
\text { deposit }\end{array}$ & $\begin{array}{l}\text { Savings } \\
\text { bonds }\end{array}$ & Bonds & Stocks & $\begin{array}{l}\text { Mutual } \\
\text { funds }\end{array}$ & $\begin{array}{c}\text { Retire- } \\
\text { ment } \\
\text { accounts }\end{array}$ & $\begin{array}{c}\text { Life } \\
\text { insurance }\end{array}$ & $\begin{array}{c}\text { Other } \\
\text { managed } \\
\text { assets }\end{array}$ & Other & $\begin{array}{l}\text { Any } \\
\text { financial } \\
\text { asset }\end{array}$ \\
\hline & \multicolumn{11}{|c|}{ F'ercentage of families holding asset } \\
\hline All families & 90.9 & 15.7 & 16.7 & 3.0 & 21.3 & 17.7 & 52.2 & 28.0 & 6.6 & 9.3 & 93.1 \\
\hline 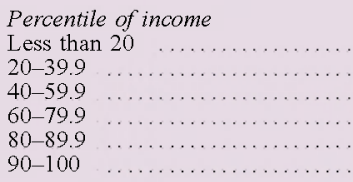 & $\begin{array}{l}70.9 \\
89.4 \\
96.1 \\
98.8 \\
99.7 \\
99.2\end{array}$ & $\begin{array}{l}10.0 \\
14.7 \\
17.4 \\
16.0 \\
18.3 \\
22.0\end{array}$ & $\begin{array}{r}3.8 \\
11.0 \\
14.1 \\
24.4 \\
30.3 \\
29.7\end{array}$ & $\begin{array}{l}* \\
* \\
1.5 \\
3.7 \\
3.9 \\
12.7\end{array}$ & $\begin{array}{r}3.8 \\
11.2 \\
16.4 \\
26.2 \\
37.0 \\
60.6\end{array}$ & $\begin{array}{r}3.6 \\
9.5 \\
15.7 \\
20.6 \\
29.0 \\
48.8\end{array}$ & $\begin{array}{l}13.2 \\
33.3 \\
52.8 \\
75.7 \\
83.7 \\
88.3\end{array}$ & $\begin{array}{l}13.8 \\
24.7 \\
25.6 \\
35.7 \\
38.6 \\
41.8\end{array}$ & $\begin{array}{r}2.2 \\
3.3 \\
5.4 \\
8.5 \\
10.7 \\
16.7\end{array}$ & $\begin{array}{r}6.2 \\
9.9 \\
9.9 \\
9.0 \\
10.8 \\
12.5\end{array}$ & $\begin{array}{l}74.8 \\
93.0 \\
98.3 \\
99.6 \\
99.8 \\
99.7\end{array}$ \\
\hline 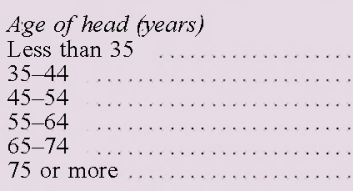 & $\begin{array}{l}86.0 \\
90.7 \\
92.2 \\
93.6 \\
93.8 \\
93.7\end{array}$ & $\begin{array}{r}6.3 \\
9.8 \\
15.2 \\
14.4 \\
29.7 \\
36.5\end{array}$ & $\begin{array}{l}12.7 \\
22.6 \\
21.0 \\
14.3 \\
11.3 \\
12.5\end{array}$ & $\begin{array}{l}* \\
2.1 \\
2.8 \\
6.1 \\
3.9 \\
5.7\end{array}$ & $\begin{array}{l}17.4 \\
21.6 \\
22.0 \\
26.7 \\
20.5 \\
21.8\end{array}$ & $\begin{array}{l}11.5 \\
17.5 \\
20.2 \\
21.3 \\
19.9 \\
19.5\end{array}$ & $\begin{array}{l}45.1 \\
61.4 \\
63.4 \\
59.1 \\
44.0 \\
25.7\end{array}$ & $\begin{array}{l}15.0 \\
27.0 \\
31.1 \\
35.7 \\
36.7 \\
33.3\end{array}$ & $\begin{array}{r}2.1 \\
3.1 \\
6.4 \\
13.0 \\
11.8 \\
11.2\end{array}$ & $\begin{array}{r}10.4 \\
9.5 \\
8.5 \\
10.6 \\
8.5 \\
7.3\end{array}$ & $\begin{array}{l}89.2 \\
93.3 \\
94.4 \\
94.8 \\
94.6 \\
95.1\end{array}$ \\
\hline $\begin{array}{l}\text { Race or ethnicity of respondent } \\
\text { White non-Hispanic } \\
\text { Nonwhite or Hispanic } \quad \ldots \ldots \ldots \ldots \ldots\end{array}$ & $\begin{array}{l}94.9 \\
78.2\end{array}$ & $\begin{array}{r}18.5 \\
6.7\end{array}$ & $\begin{array}{r}19.4 \\
7.8\end{array}$ & $\begin{array}{r}3.8 \\
.4\end{array}$ & $\begin{array}{l}24.5 \\
11.0\end{array}$ & $\begin{array}{r}20.9 \\
7.2\end{array}$ & $\begin{array}{l}56.9 \\
37.3\end{array}$ & $\begin{array}{l}29.8 \\
22.3\end{array}$ & $\begin{array}{l}8.2 \\
1.8\end{array}$ & $\begin{array}{l}9.2 \\
9.7\end{array}$ & $\begin{array}{l}96.5 \\
82.4\end{array}$ \\
\hline $\begin{array}{l}\text { Current work status of head } \\
\text { Working for someone else } \ldots \ldots \\
\text { Self-employed } \ldots \ldots \ldots \ldots \ldots \ldots \\
\text { Retired } \ldots \ldots \ldots \ldots \ldots \ldots \ldots \ldots \\
\text { Other not working } \ldots \ldots \ldots \ldots \ldots \ldots\end{array}$ & $\begin{array}{l}92.4 \\
95.2 \\
88.9 \\
70.5\end{array}$ & $\begin{array}{r}11.3 \\
18.7 \\
27.0 \\
8.3\end{array}$ & $\begin{array}{r}19.4 \\
16.6 \\
11.4 \\
7.5\end{array}$ & $\begin{array}{l}2.0 \\
6.1 \\
4.5 \\
*\end{array}$ & $\begin{array}{l}20.9 \\
29.8 \\
19.7 \\
13.2\end{array}$ & $\begin{array}{l}17.3 \\
22.9 \\
17.3 \\
10.8\end{array}$ & $\begin{array}{l}61.5 \\
58.9 \\
29.1 \\
27.3\end{array}$ & $\begin{array}{l}27.4 \\
34.6 \\
29.1 \\
12.8\end{array}$ & $\begin{array}{r}5.3 \\
6.9 \\
10.4 \\
5.6\end{array}$ & $\begin{array}{r}9.4 \\
12.4 \\
7.9 \\
6.5\end{array}$ & $\begin{array}{l}94.7 \\
97.4 \\
90.8 \\
72.9\end{array}$ \\
\hline $\begin{array}{l}\text { Housing status } \\
\text { Owner } \ldots \ldots \ldots \ldots \ldots \ldots \ldots \ldots \\
\text { Renter or other } \ldots \ldots \ldots \ldots \ldots \ldots\end{array}$ & $\begin{array}{l}96.5 \\
79.3\end{array}$ & $\begin{array}{r}20.0 \\
6.7\end{array}$ & $\begin{array}{r}21.2 \\
7.2\end{array}$ & $\begin{array}{r}4.0 \\
.7\end{array}$ & $\begin{array}{r}27.0 \\
9.3\end{array}$ & $\begin{array}{r}22.7 \\
7.1\end{array}$ & $\begin{array}{l}62.6 \\
30.4\end{array}$ & $\begin{array}{l}34.5 \\
14.3\end{array}$ & $\begin{array}{l}8.9 \\
2.0\end{array}$ & $\begin{array}{r}8.8 \\
10.4\end{array}$ & $\begin{array}{l}97.7 \\
83.5\end{array}$ \\
\hline 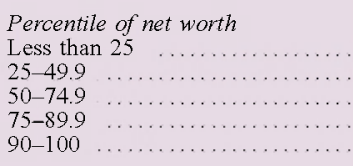 & $\begin{array}{l}72.4 \\
93.6 \\
98.2 \\
99.6 \\
99.6\end{array}$ & $\begin{array}{r}1.8 \\
8.8 \\
23.2 \\
30.1 \\
26.9\end{array}$ & $\begin{array}{r}4.3 \\
12.8 \\
23.5 \\
25.9 \\
26.3\end{array}$ & $\begin{array}{c}* \\
* \\
* \\
5.3 \\
18.4\end{array}$ & $\begin{array}{r}5.0 \\
9.5 \\
20.3 \\
41.2 \\
64.3\end{array}$ & $\begin{array}{r}2.5 \\
7.2 \\
17.5 \\
35.9 \\
54.8\end{array}$ & $\begin{array}{l}18.9 \\
45.3 \\
63.2 \\
77.6 \\
87.4\end{array}$ & $\begin{array}{r}6.9 \\
26.0 \\
34.5 \\
41.7 \\
48.6\end{array}$ & $\begin{array}{r}* \\
1.3 \\
6.2 \\
13.9 \\
26.4\end{array}$ & $\begin{array}{r}7.9 \\
8.6 \\
8.7 \\
9.4 \\
16.1\end{array}$ & $\begin{array}{r}77.2 \\
96.5 \\
98.9 \\
99.8 \\
100.0\end{array}$ \\
\hline & \multicolumn{11}{|c|}{ 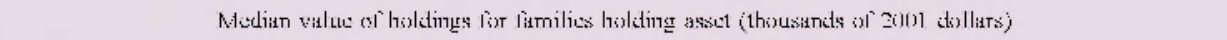 } \\
\hline All families $\ldots \ldots \ldots \ldots$. & 4.0 & 15.0 & 1.0 & 43.5 & 20.0 & 35.0 & 29.0 & 10.0 & 70.0 & 4.0 & 28.0 \\
\hline 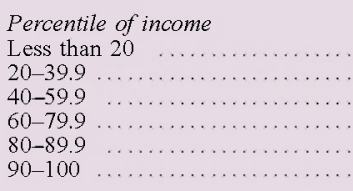 & $\begin{array}{r}.9 \\
1.9 \\
2.9 \\
5.3 \\
9.5 \\
26.0\end{array}$ & $\begin{array}{l}10.0 \\
14.0 \\
13.0 \\
15.0 \\
13.0 \\
25.0\end{array}$ & $\begin{array}{r}1.0 \\
.6 \\
.5 \\
1.0 \\
1.0 \\
2.0\end{array}$ & $\begin{array}{c}* \\
* \\
10.0 \\
40.0 \\
50.0 \\
88.7\end{array}$ & $\begin{array}{r}7.5 \\
10.0 \\
7.0 \\
17.0 \\
20.0 \\
50.0\end{array}$ & $\begin{array}{l}21.0 \\
24.0 \\
24.0 \\
30.0 \\
28.0 \\
87.5\end{array}$ & $\begin{array}{r}4.5 \\
8.0 \\
13.6 \\
30.0 \\
55.0 \\
130.0\end{array}$ & $\begin{array}{r}3.6 \\
6.2 \\
7.0 \\
12.0 \\
10.0 \\
24.0\end{array}$ & $\begin{array}{r}24.2 \\
36.0 \\
70.0 \\
60.0 \\
70.0 \\
112.0\end{array}$ & $\begin{array}{r}1.7 \\
3.0 \\
3.0 \\
3.0 \\
7.0 \\
15.0\end{array}$ & $\begin{array}{r}2.0 \\
8.0 \\
17.1 \\
55.5 \\
97.1 \\
364.0\end{array}$ \\
\hline 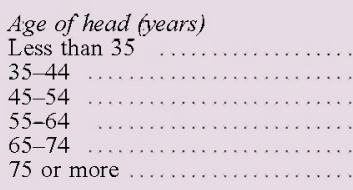 & $\begin{array}{l}1.8 \\
3.4 \\
4.6 \\
5.5 \\
8.0 \\
7.3\end{array}$ & $\begin{array}{r}4.0 \\
6.0 \\
12.0 \\
19.0 \\
20.0 \\
25.0\end{array}$ & $\begin{array}{r}.3 \\
1.0 \\
1.0 \\
2.5 \\
2.0 \\
3.0\end{array}$ & $\begin{array}{c}* \\
13.6 \\
60.0 \\
60.0 \\
71.4 \\
35.0\end{array}$ & $\begin{array}{r}5.7 \\
15.0 \\
15.0 \\
37.5 \\
85.0 \\
60.0\end{array}$ & $\begin{array}{r}9.0 \\
17.5 \\
38.5 \\
60.0 \\
70.0 \\
70.0\end{array}$ & $\begin{array}{r}6.6 \\
28.5 \\
48.0 \\
55.0 \\
60.0 \\
46.0\end{array}$ & $\begin{array}{r}10.0 \\
9.0 \\
11.0 \\
10.0 \\
8.8 \\
7.0\end{array}$ & $\begin{array}{r}40.0 \\
50.0 \\
60.0 \\
55.0 \\
120.0 \\
100.0\end{array}$ & $\begin{array}{r}1.3 \\
2.0 \\
5.0 \\
10.0 \\
8.0 \\
17.5\end{array}$ & $\begin{array}{r}6.3 \\
26.9 \\
45.7 \\
56.6 \\
51.4 \\
40.0\end{array}$ \\
\hline $\begin{array}{l}\text { Race or ethnicity of respondent } \\
\text { White non-Hispanic } \ldots \ldots \ldots \ldots \\
\text { Nonwhite or Hispanic } \quad \ldots \ldots \ldots \ldots\end{array}$ & $\begin{array}{l}4.8 \\
1.7\end{array}$ & $\begin{array}{r}15.0 \\
9.0\end{array}$ & $\begin{array}{r}1.0 \\
.7\end{array}$ & $\begin{array}{r}50.0 \\
7.6\end{array}$ & $\begin{array}{r}22.0 \\
8.0\end{array}$ & $\begin{array}{l}40.0 \\
17.5\end{array}$ & $\begin{array}{l}35.0 \\
10.0\end{array}$ & $\begin{array}{r}10.0 \\
8.1\end{array}$ & $\begin{array}{l}70.0 \\
45.0\end{array}$ & $\begin{array}{l}5.0 \\
1.7\end{array}$ & $\begin{array}{r}38.5 \\
7.2\end{array}$ \\
\hline $\begin{array}{l}\text { Current work status of head } \\
\text { Working for someone else } \ldots \ldots \\
\text { Self-employed } \ldots \ldots \ldots \ldots \ldots \ldots \\
\text { Retired } \ldots \ldots \ldots \ldots \ldots \ldots \ldots \\
\text { Other not working } \ldots \ldots \ldots \ldots \ldots \ldots\end{array}$ & $\begin{array}{l}3.2 \\
8.5 \\
5.0 \\
1.9\end{array}$ & $\begin{array}{r}9.0 \\
16.0 \\
25.0 \\
40.0\end{array}$ & $\begin{array}{r}1.0 \\
2.0 \\
4.0 \\
.3\end{array}$ & $\begin{array}{l}26.0 \\
71.9 \\
50.1 \\
*\end{array}$ & $\begin{array}{r}11.0 \\
35.0 \\
60.0 \\
8.0\end{array}$ & $\begin{array}{l}20.0 \\
98.0 \\
70.0 \\
40.0\end{array}$ & $\begin{array}{l}24.5 \\
54.6 \\
54.0 \\
20.0\end{array}$ & $\begin{array}{r}9.5 \\
17.0 \\
9.0 \\
10.0\end{array}$ & $\begin{array}{r}55.0 \\
109.0 \\
100.0 \\
39.0\end{array}$ & $\begin{array}{r}2.5 \\
12.0 \\
10.0 \\
2.0\end{array}$ & $\begin{array}{r}24.3 \\
61.0 \\
32.5 \\
6.2\end{array}$ \\
\hline $\begin{array}{l}\text { Housing status } \\
\text { Owner } \ldots \ldots \ldots \ldots \ldots \ldots \ldots \ldots \\
\text { Renter or other } \ldots \ldots \ldots \ldots \ldots \ldots \ldots\end{array}$ & $\begin{array}{l}5.8 \\
1.2\end{array}$ & $\begin{array}{l}15.0 \\
10.0\end{array}$ & $\begin{array}{r}1.2 \\
.4\end{array}$ & $\begin{array}{l}50.0 \\
29.6\end{array}$ & $\begin{array}{r}22.0 \\
6.3\end{array}$ & $\begin{array}{l}40.0 \\
10.0\end{array}$ & $\begin{array}{r}38.2 \\
6.8\end{array}$ & $\begin{array}{r}10.0 \\
7.5\end{array}$ & $\begin{array}{l}70.0 \\
40.0\end{array}$ & $\begin{array}{l}6.0 \\
2.0\end{array}$ & $\begin{array}{r}50.5 \\
3.9\end{array}$ \\
\hline 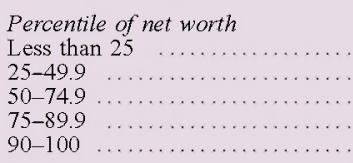 & $\begin{array}{r}.7 \\
2.2 \\
5.5 \\
13.7 \\
36.0\end{array}$ & $\begin{array}{r}1.5 \\
5.0 \\
11.5 \\
20.0 \\
40.0\end{array}$ & $\begin{array}{r}.2 \\
.5 \\
1.0 \\
2.0 \\
2.0\end{array}$ & $\begin{array}{c}* \\
* \\
* \\
20.0 \\
90.0\end{array}$ & $\begin{array}{r}1.3 \\
3.2 \\
8.3 \\
25.6 \\
122.0\end{array}$ & $\begin{array}{r}2.0 \\
5.0 \\
15.0 \\
37.5 \\
140.0\end{array}$ & $\begin{array}{r}2.0 \\
7.5 \\
30.0 \\
76.5 \\
190.0\end{array}$ & $\begin{array}{r}1.8 \\
5.2 \\
9.0 \\
12.0 \\
30.0\end{array}$ & $\begin{array}{c}* \\
10.1 \\
22.0 \\
70.0 \\
200.0\end{array}$ & $\begin{array}{r}1.0 \\
2.3 \\
4.5 \\
10.0 \\
30.0\end{array}$ & $\begin{array}{r}1.3 \\
10.6 \\
53.1 \\
201.7 \\
707.4\end{array}$ \\
\hline
\end{tabular}

Note. See note to table 1.

*Ten or fewer observations. 
on workers' salaries and years of work with an employer, a group of employers, or a union. Unfortunately, income streams from OASI and definedbenefit plans cannot be translated directly into a current value because valuation depends critically on assumptions about future events and conditionswork decisions, earnings, inflation rates, discount rates, mortality, and so on-and no widely agreedupon standards exist for making these assumptions. ${ }^{12}$

However, the SCF does contain substantial information (not shown in tables) for family heads and their working spouses or partners regarding the defined-benefit and account-type plans to which families have rights; the survey also collects data on benefits that are being received or will be received. In $2001,57.1$ percent of families had rights to some type of plan other than OASI through current or past work, a level virtually the same as in 1998 . Of such families in $2001,43.5$ percent had only an account-type plan, 35.3 percent had only a defined-benefit plan, and 21.1 percent had both. Comparable data are not available for all types of pensions in 1998. However, when attention is restricted to plans offered through the current job of the family head or that person's spouse or partner, the distribution of plan types is about the same in 1998 and 2001; this result stands in contrast to evidence from earlier surveys that shows a continuing shift toward account-type plans.

In many account-type pension plans, contributions may be made by the employer, the worker, or both. In some cases these contributions represent a substantial amount of saving, though workers may offset this saving by reducing their saving in other forms. Employer's contributions also represent additional income for the worker. In 2001, 86.0 percent of families with account-type plans on a current job had employers who made contributions to the plan, and 87.0 percent of families with such plans made contributions themselves.

The eligibility of working family heads to participate in some type of job-related pension rose from 55.0 percent in 1998 to 57.1 percent 2001. Participation by eligible workers is usually voluntary. In 2001, 26.2 percent of family heads who were eligible to participate failed to do so, up from 23.2 percent in 1998. The choice to participate appears to be related strongly to income. Of heads of families with income

12. For one possible calculation of net worth that includes the annuity value of defined-benefit pension benefits and OASI payments, see Arthur B. Kennickell and Annika E. Sunden, "Pensions, Social Security, and the Distribution of Wealth," Finance and Economics Discussion Series 1997-55 (Board of Governors of the Federal Reserve System, October 1997). Papers in this series from 1996 to date are available at www.federalreserve.gov/pubs/feds in the lowest 20 percent of the distribution, 46.4 percent who were eligible declined to participate; in contrast, among heads of families with incomes in the highest 10 percent of the distribution, only 15.3 percent of eligible workers declined to participate. Among family heads who were eligible but chose not to participate, 32.9 percent were covered by a defined-benefit plan, a level down from 35.8 percent in 1998.

\section{Cash Value Life Insurance}

Cash value life insurance combines an investment vehicle with insurance coverage in the form of a death benefit. ${ }^{13}$ Some cash value policies offer a high degree of choice in the way the policy payments are invested. Investment returns on cash value life insurance are typically shielded from taxation until the money is withdrawn; if the funds remain untapped until the policyholder dies, the beneficiary of the policy may receive, tax-free, the death benefit or the cash value, whichever is greater. In contrast, term insurance, the other popular life insurance type, offers only a death benefit. One attraction of cash value policies for some people is the fact that it promotes regular saving funded through the required policy premium.

Ownership of cash value policies is widespread, with a tendency toward higher levels among families with higher levels of income and wealth. From 1998 to 2001, ownership of such policies declined 1.6 percent, to 28.0 percent, a movement that continues an earlier trend of falling ownership. Decreases were broadly spread over demographic groups. The decline in ownership of cash value policies appears to reflect, in part, a decline in ownership of any type of life insurance.

Over the three-year period, ownership of any type of life insurance for anyone in the family dropped from 72.0 percent of families to 69.3 percent (not shown in tables). Among those with policies, term insurance has become relatively more popular, perhaps because it offers higher levels of death benefits for a given premium and is widely available as an employer-provided benefit; moreover, cash value insurance is competing with an expanding set of alternatives for investment.

The median holdings of cash value insurance for families that had any has been rising over the 19922001 period. It rose 26.6 percent over the most recent

13. The survey measures the value of such policies according to their current cash value, not their death benefit. 
three-year period, during which gains were spread across most groups. The broad increase in typical holdings suggests that the decline in ownership removed families with relatively small holdings. A possible explanation of the rise in ownership and use among families in the oldest age group may be the more intensive use of such policies for estate planning; as for the increase among the younger families, they may regard such contractually determined saving as a convenient way to start a saving plan.

\section{Other Managed Assets}

Ownership of other managed assets-personal annuities and trusts with an equity interest and managed investment accounts - is concentrated among families with higher levels of income and wealth and among families headed by persons aged 55 and older. From 1998 to 2001, overall ownership of these assets rose 0.7 percentage point. Among the component assets, a small decline in ownership of annuities was offset by increases for trusts and managed investment accounts (not shown in tables). Ownership increased markedly among families with incomes in the highest 20 percent of the distribution and with net worth in the top quarter of the distribution.

Between 1998 and 2001, the median value of such managed assets more than doubled to $\$ 70,000$, a move paralleling the increase noted earlier in the share of other managed assets in total financial assets. At the same time, holdings increased for almost all demographic groups, and some of the proportional increases were large. Although these assets are not broadly held, close examination of the data indicates that the increases are not driven by outliers; rather, the distribution of holdings appears to have simply risen overall. In terms of the underlying components, overall holdings of managed investment accounts increased more rapidly than holdings of trusts, which in turn increased more rapidly than annuities (not shown in tables).

\section{Other Financial Assets}

For other financial assets - a heterogeneous category including oil and gas leases, futures contracts, royalties, proceeds from lawsuits or estates in settlement, and loans made to others - ownership was about unchanged in the three-year period. Ownership of such assets tends to be more common among higher income and wealth groups. Changes in ownership across demographic groups were mixed, but median holdings for those who had such assets rose 21.2 percent, to $\$ 4,000$.

Some publicly traded companies offer stock options to their employees as a form of compensation. ${ }^{14}$ Although stock options, when executed, may represent an appreciable part of a family's net worth, the survey does not specifically ask for the value of these options. ${ }^{15}$ Instead, the survey asks whether the family head or that person's spouse or partner had been given stock options by an employer during the preceding year. ${ }^{16}$ In 2001, 11.4 percent of families reported having received stock options, a share virtually the same as in 1998 (not shown in tables).

Direct and Indirect Holdings

of Publicly Traded Stocks

Families may hold stocks in publicly traded companies directly or indirectly, and information about each of these forms of ownership is collected separately in the SCF. When direct and indirect forms are combined, the data show considerable growth in stock ownership from 1992 (table 6). In 2001, 51.9 percent of families held stock in some form, a level 3 percentage points above that in 1998. Ownership rates tend to be highest among families with higher incomes and families headed by persons aged 35 to 64 . Over the most recent three-year period, ownership rates rose for almost all the groups shown.

The median value of direct and indirect stock holdings for those who had stock rose from $\$ 27,200$ in 1998 to $\$ 34,300$ in 2001 , a 26.1 percent gain that was spread over most of the demographic groups. The median more than doubled for the groups of families headed by persons aged 65 and more. At the same time, the ratio of the value of all families' stocks to the value of all families' financial assets rose 2.1 percentage points.

14. See David Lebow, Louise Sheiner, Larry Slifman, and Martha Starr-McCluer, "Recent Trends in Compensation Practices," Finance and Economics Discussion Series 1999-32 (Board of Governors of the Federal Reserve System, July 1999).

15. Because such options are typically not publicly traded or their execution is otherwise constrained, their value is uncertain until the exercise date; until then, meaningful valuation would require complex assumptions about future movements in stock prices.

16. In theory, families in the survey might have had a good idea of the value of options they had received from their employers and included that value in their reports of miscellaneous assets. However, in the 2001 survey, only one family reported receiving options from an employer and reported options as a miscellaneous asset, and in that case the two sets of options may not have been the same; no family made such a report in the 1998 survey. 
6. Direct and indirect family holdings of stock, by selected characteristics of families, 1992, 1995, 1998 , and 2001 surveys Percent except as noted

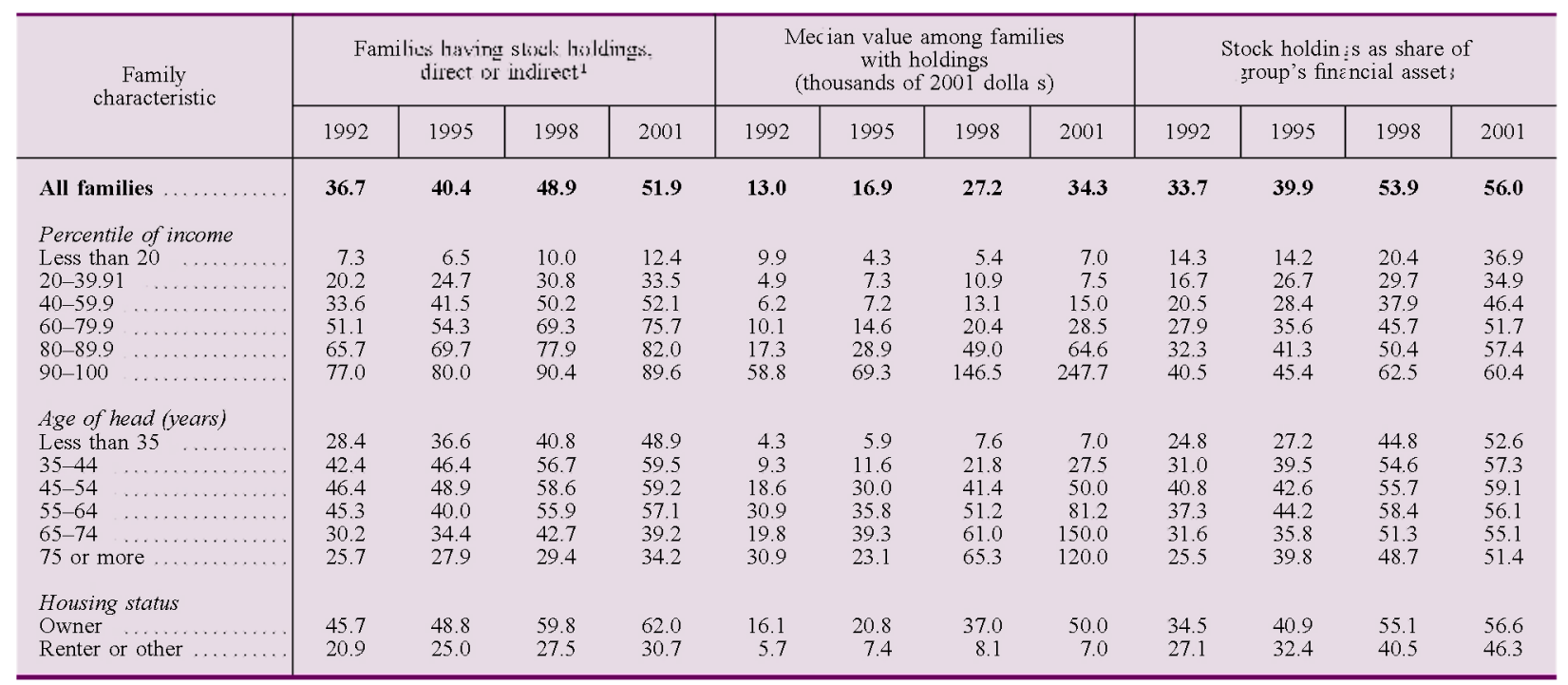

Note. See note to table 1

1. Indirect holdings are those in mutual funds, retirement accounts, and other managed assets

\section{Nonfinancial Assets}

The value of nonfinancial assets as a proportion of the value of the total assets of all families fell from 59.3 percent in 1998 to 58.0 percent in 2001 (table 7). Primary residences retained their earlier relative importance, while equity in nonresidential real estate and business equity moved up in relative importance. The shares of motor vehicles, other residential property, and the residual "other" category declined.

The level of ownership of any type of nonfinancial asset in the 2001 survey is above 80 percent for most groups - exceptions are the lowest income and wealth groups, nonwhite or Hispanic families, families headed by persons who were neither working nor retired, and renters (table 8). The owner-

7. Value of nonfinancial assets of all families, distributed by type of asset, 1992, 1995, 1998, and 2001 surveys Percent

\begin{tabular}{|c|c|c|c|c|}
\hline Type of nonfinancial asset & 1992 & 1995 & 1998 & 2001 \\
\hline Vehicles & 5.7 & 7.1 & 6.5 & 5.9 \\
\hline Primary residence & 47.0 & 47.5 & 47.0 & 46.8 \\
\hline Other residential property & 8.5 & 8.0 & 8.5 & 8.1 \\
\hline \multicolumn{5}{|l|}{ Equity in nonresidential } \\
\hline property ........... & 109 & 79 & 7.7 & 8.2 \\
\hline Business equity $\quad . \ldots \ldots$ & 26.3 & 27.2 & 28.5 & 29.3 \\
\hline Other .. & 1.6 & 2.3 & 1.8 & 1.6 \\
\hline Total & 100 & 100 & 100 & 100 \\
\hline \multicolumn{5}{|l|}{ МeMo } \\
\hline $\begin{array}{l}\text { Nonfinancial assets as a } \\
\text { share of total assets }\end{array}$ & 68.4 & 63.3 & 59.3 & 58.0 \\
\hline
\end{tabular}

ship rate is well over 90 percent for many groups. The proportion of families with nonfinancial assets in 2001 was 0.8 percent higher than in 1998 . By demographic group, increases in ownership were more common than decreases, and the decreases were 1 percentage point or less. The median holding for those with such assets rose 6.4 percent, and the median also rose for all demographic groups except for families headed by retired persons. Gains were most notable for families in the highest income and net worth groups, white non-Hispanic families, and families headed by self-employed persons or by persons who were neither working nor retired.

\section{Vehicles}

Vehicles continue to be the most commonly held nonfinancial asset. ${ }^{17}$ Over the three-year period, the share of families that owned some type of vehicle rose 2 percentage points, to 84.8 percent, a level that is still about $1 / 2$ percentage point below the 1992 level. The decline since 1992 reflects, in part, a substitution of other modes of ownership (not shown in tables): The use of leased vehicles rose from 2.9 percent to 5.8 percent in the nine-year period, and the personal use of vehicles provided by employers

17. The definition of vehicles here is a broad one that includes cars, vans, sport utility vehicles, trucks, motor homes, recreational vehicles, motorcycles, boats, airplanes, and helicopters. 
rose from 3.8 percent to 9.1 percent. The share of families that had at least one vehicle for personal use (whether owned or not) increased to 87.8 percent in 2001 after holding steady near 87 percent from 1992 to 1998 .

The median market value of vehicles for those who owned at least one rose 14.4 percent from 1998 to 2001; all demographic groups shared in this gain. Underlying this increase was a nearly 50 percent rise - from 10.6 percent to 15.2 percent - in the fraction of total vehicle value attributable to sport utility vehicles, which are generally more expensive than standard automobiles (not shown in tables).

Primary Residence

and Other Residential Real Estate

From 1998 to 2001, the proportion of families owning a principal residence rose 1.5 percentage points, to 67.7 percent; the increase continued earlier trends. ${ }^{18}$ For 2001, the homeownership rate was below average for nonwhite or Hispanic families and family groups with relatively low incomes, headed by persons who were neither retired nor selfemployed, with relatively low wealth, and headed by persons aged less than 35 . Increases in ownership during the period were widespread. However, of the groups with below-average ownership, the ownership rate rose by more than the overall rate of increase only among the two lowest income groups and the group of families headed by persons who were neither working nor retired; others of these groups saw very small increases or actual declines in ownership.

Over the three-year period, the overall median home value rose 12.1 percent, to $\$ 122,000$. Only two groups of homeowners saw the median value of their residences fall over the period: families with incomes in the second quintile of the distribution and nonwhite or Hispanic families. The small decline for nonwhite or Hispanic families did not offset the larger-than-average gains for this group seen in the previous surveys since 1992.

In 2001, 11.3 percent of families owned some form of residential real estate besides a primary residence (second homes, time shares, one- to four-family rental properties, and other types of residential property), down from 12.8 percent in 1998. Ownership is much more common among the highest income and wealth groups and among families headed by self-

18. This measure of principal residences comprises mobile homes and their sites, the part of farms and ranches not used for the farming or ranching business, condominiums, cooperatives, townhouses, detached single-family homes, and other permanent dwellings. employed persons; by age group, ownership rises to a peak in the 55-to-64 group and then declines. Although the median value of such property rose 13.0 percent in the three-year period, changes by demographic group show a mixed pattern of gains and losses, some of them substantial.

\section{Net Equity in Nonresidential Real Estate}

The ownership of nonresidential real estate edged down from 8.6 percent of families in 1998 to 8.3 percent in 2001. ${ }^{19}$ Ownership is most common among the highest income and wealth groups and among families headed by persons aged 45 to 74 . Between 1998 and 2001, ownership went down for most groups. At the same time, the overall median holding for those with such real estate increased 18.4 percent. Holdings rose for most income and age groupssometimes by a large amount - but by wealth group the only notable increase was in the highest 10 percent of the distribution.

\section{Net Equity in Privately Held Businesses}

In $2001,11.8$ percent of families owned privately held business interests, a proportion that has changed little since the redesign of the SCF in $1989 .{ }^{20}$ Ownership is most common among families with higher levels of income and wealth and among families headed by persons aged between 45 and 74 . By demographic group, declines in ownership from 1998 to 2001 were more common than increases, and even the proportion of the self-employed group that also owned a business declined. ${ }^{21}$ At the same time, ownership among two groups increased notably: families with incomes in the highest 10 percent of the distribution and those with net worth in the 75th through 90th percentiles of the distribution.

19. Nonresidential real estate comprises the following types of property unless they are owned through a business: commercial property, rental property with five or more units, farm land, undeveloped land, and all other types of nonresidential real estate.

20. The forms of business in this category are sole proprietorships, limited partnerships, other types of partnerships, subchapter $S$ corporations and other types of corporations that are not publicly traded, limited liability companies, and other types of private businesses. If the family surveyed lived on a farm or ranch that was used at least in part for agricultural business, the value of that part net of the corresponding share of associated debts was included with other business assets; these allocations of debts to farming and ranching businesses represent change in definition from that used in the January 2000 Federal Reserve Bulletin article on the $1998 \mathrm{SCF}$.

21. In the survey, self-employment status and business ownership are independently determined. 
8. Family holdings of nonfinancial assets and of any asset, by selected characteristics of families and type of asset, 1998 and 2001 surveys

A. 1998 Survey of Consumer Finances

\begin{tabular}{|c|c|c|c|c|c|c|c|c|}
\hline $\begin{array}{c}\text { Family } \\
\text { characteristic }\end{array}$ & Vehicles & $\begin{array}{l}\text { Primary } \\
\text { residence }\end{array}$ & $\begin{array}{l}\text { Other } \\
\text { residential } \\
\text { property }\end{array}$ & $\begin{array}{c}\text { Equity in } \\
\text { nonresidential } \\
\text { property }\end{array}$ & $\begin{array}{l}\text { Business } \\
\text { equity }\end{array}$ & Other & $\begin{array}{l}\text { Any } \\
\text { nonfinancial } \\
\text { asset }\end{array}$ & $\begin{array}{l}\text { Any } \\
\text { asset }\end{array}$ \\
\hline & \multicolumn{8}{|c|}{ F'ercentage of families holting asset } \\
\hline All families & 82.8 & 66.2 & 12.8 & 8.6 & 11.5 & 8.5 & 89.9 & 96.8 \\
\hline 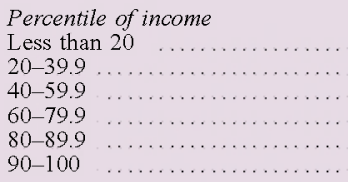 & $\begin{array}{l}58.7 \\
81.9 \\
89.2 \\
93.0 \\
92.8 \\
90.0\end{array}$ & $\begin{array}{l}38.8 \\
55.3 \\
67.3 \\
79.1 \\
88.2 \\
93.1\end{array}$ & $\begin{array}{r}1.9 \\
6.8 \\
11.8 \\
17.0 \\
17.7 \\
35.5\end{array}$ & $\begin{array}{r}2.1 \\
6.1 \\
7.7 \\
9.5 \\
14.1 \\
21.1\end{array}$ & $\begin{array}{r}3.8 \\
5.7 \\
9.0 \\
13.9 \\
18.8 \\
31.0\end{array}$ & $\begin{array}{r}2.3 \\
7.4 \\
8.9 \\
10.5 \\
9.4 \\
17.0\end{array}$ & $\begin{array}{l}68.7 \\
89.5 \\
95.4 \\
97.3 \\
98.5 \\
99.0\end{array}$ & $\begin{array}{r}87.1 \\
98.1 \\
99.2 \\
99.8 \\
100.0 \\
100.0\end{array}$ \\
\hline 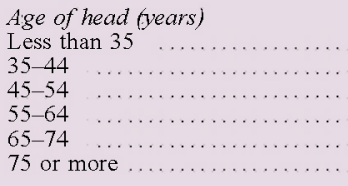 & $\begin{array}{l}78.3 \\
85.8 \\
87.5 \\
88.7 \\
83.4 \\
69.8\end{array}$ & $\begin{array}{l}38.9 \\
67.1 \\
74.4 \\
80.3 \\
81.5 \\
77.0\end{array}$ & $\begin{array}{r}3.5 \\
12.2 \\
16.2 \\
20.4 \\
18.4 \\
13.6\end{array}$ & $\begin{array}{r}2.7 \\
7.5 \\
12.2 \\
10.4 \\
15.3 \\
8.1\end{array}$ & $\begin{array}{r}7.2 \\
14.7 \\
16.2 \\
14.3 \\
10.1 \\
2.7\end{array}$ & $\begin{array}{r}7.3 \\
8.8 \\
9.2 \\
8.5 \\
10.3 \\
7.0\end{array}$ & $\begin{array}{l}83.3 \\
92.1 \\
92.9 \\
93.8 \\
92.0 \\
87.2\end{array}$ & $\begin{array}{l}94.8 \\
97.6 \\
96.7 \\
98.2 \\
98.5 \\
96.4\end{array}$ \\
\hline $\begin{array}{l}\text { Race or ethnicity of respondent } \\
\text { White non-Hispanic } \quad \ldots \ldots \ldots \ldots \\
\text { Nonwhite or Hispanic } \quad \ldots \ldots \ldots\end{array}$ & $\begin{array}{l}87.3 \\
67.2\end{array}$ & $\begin{array}{l}71.8 \\
46.8\end{array}$ & $\begin{array}{r}14.1 \\
8.4\end{array}$ & $\begin{array}{l}9.4 \\
5.8\end{array}$ & $\begin{array}{r}13.2 \\
5.4\end{array}$ & $\begin{array}{r}10.0 \\
3.1\end{array}$ & $\begin{array}{l}93.8 \\
76.4\end{array}$ & $\begin{array}{l}98.8 \\
89.9\end{array}$ \\
\hline $\begin{array}{l}\text { Current work status of head } \\
\text { Working for someone else } \\
\text { Self-employed } \quad \ldots \ldots \ldots \ldots \ldots \\
\text { Retired } \ldots \ldots \ldots \ldots \ldots \ldots \\
\text { Other not working } \ldots \ldots \ldots \ldots \ldots\end{array}$ & $\begin{array}{l}87.6 \\
89.5 \\
73.3 \\
58.5\end{array}$ & $\begin{array}{l}63.5 \\
81.3 \\
72.4 \\
35.8\end{array}$ & $\begin{array}{r}10.6 \\
25.3 \\
14.3 \\
4.5\end{array}$ & $\begin{array}{r}6.7 \\
17.7 \\
10.1 \\
3.6\end{array}$ & $\begin{array}{r}5.5 \\
63.4 \\
3.6 \\
3.7\end{array}$ & $\begin{array}{r}8.8 \\
13.3 \\
6.4 \\
3.4\end{array}$ & $\begin{array}{l}92.4 \\
98.1 \\
85.2 \\
66.3\end{array}$ & $\begin{array}{l}98.2 \\
99.2 \\
94.7 \\
85.7\end{array}$ \\
\hline $\begin{array}{l}\text { Housing status } \\
\text { Owner } \ldots \ldots \ldots \ldots \ldots \ldots \ldots \ldots \ldots \\
\text { Renter or other } \ldots \ldots \ldots \ldots \ldots \ldots\end{array}$ & $\begin{array}{l}90.6 \\
67.6\end{array}$ & $\begin{array}{l}100.0 \\
\ldots\end{array}$ & $\begin{array}{r}16.8 \\
5.1\end{array}$ & $\begin{array}{r}11.3 \\
3.3\end{array}$ & $\begin{array}{r}14.5 \\
5.4\end{array}$ & $\begin{array}{l}9.5 \\
6.4\end{array}$ & $\begin{array}{r}100.0 \\
70.1\end{array}$ & $\begin{array}{r}100.0 \\
90.7\end{array}$ \\
\hline 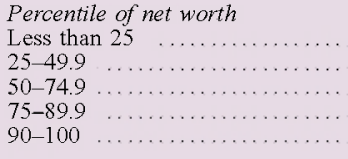 & $\begin{array}{l}62.3 \\
87.4 \\
90.4 \\
90.8 \\
92.0\end{array}$ & $\begin{array}{l}14.0 \\
67.3 \\
89.3 \\
94.0 \\
95.1\end{array}$ & $\begin{array}{r}* \\
5.8 \\
11.8 \\
26.2 \\
41.7\end{array}$ & $\begin{array}{r}* \\
3.6 \\
7.8 \\
16.8 \\
30.5\end{array}$ & $\begin{array}{r}1.4 \\
6.4 \\
10.6 \\
17.9 \\
41.4\end{array}$ & $\begin{array}{r}2.7 \\
8.0 \\
8.9 \\
11.4 \\
18.8\end{array}$ & $\begin{array}{l}65.2 \\
96.0 \\
99.1 \\
99.2 \\
99.6\end{array}$ & $\begin{array}{r}87.4 \\
100.0 \\
100.0 \\
100.0 \\
100.0\end{array}$ \\
\hline & \multicolumn{8}{|c|}{ 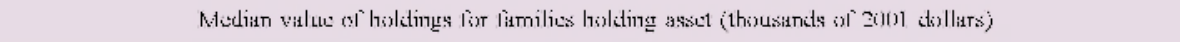 } \\
\hline All families ....... & 11.8 & 108.8 & 70.8 & 41.4 & 65.3 & 10.9 & 106.4 & 134.2 \\
\hline 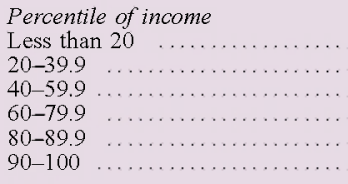 & $\begin{array}{r}4.5 \\
6.9 \\
10.5 \\
15.3 \\
20.1 \\
27.7\end{array}$ & $\begin{array}{r}59.9 \\
81.6 \\
92.5 \\
119.7 \\
149.1 \\
244.9\end{array}$ & $\begin{array}{r}87.1 \\
65.3 \\
51.7 \\
70.8 \\
58.0 \\
131.4\end{array}$ & $\begin{array}{r}10.9 \\
26.1 \\
29.9 \\
32.7 \\
32.7 \\
124.1\end{array}$ & $\begin{array}{r}31.3 \\
42.5 \\
43.5 \\
54.4 \\
54.4 \\
239.5\end{array}$ & $\begin{array}{r}5.4 \\
5.4 \\
6.5 \\
10.9 \\
10.9 \\
32.7\end{array}$ & $\begin{array}{r}24.3 \\
56.9 \\
85.3 \\
134.5 \\
179.1 \\
360.6\end{array}$ & $\begin{array}{r}16.3 \\
66.5 \\
115.7 \\
202.3 \\
295.5 \\
660.2\end{array}$ \\
\hline 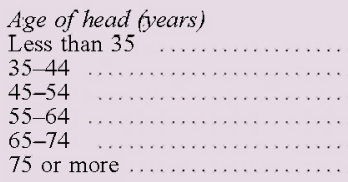 & $\begin{array}{r}9.7 \\
12.4 \\
13.9 \\
14.7 \\
11.8 \\
7.6\end{array}$ & $\begin{array}{r}91.4 \\
109.9 \\
130.6 \\
119.7 \\
103.4 \\
92.5\end{array}$ & $\begin{array}{r}46.3 \\
49.0 \\
80.5 \\
76.2 \\
81.6 \\
112.1\end{array}$ & $\begin{array}{l}27.2 \\
21.8 \\
49.0 \\
58.8 \\
49.0 \\
58.8\end{array}$ & $\begin{array}{r}37.0 \\
68.0 \\
108.8 \\
68.0 \\
72.1 \\
43.5\end{array}$ & $\begin{array}{r}5.4 \\
8.7 \\
15.2 \\
30.5 \\
10.9 \\
10.9\end{array}$ & $\begin{array}{r}24.7 \\
112.6 \\
138.0 \\
138.2 \\
119.6 \\
104.6\end{array}$ & $\begin{array}{r}31.5 \\
139.3 \\
194.7 \\
215.7 \\
178.6 \\
146.9\end{array}$ \\
\hline $\begin{array}{l}\text { Race or ethnicity of respondent } \\
\text { White non-Hispanic } \quad \ldots \ldots \ldots \ldots \\
\text { Nonwhite or Hispanic } \quad \ldots \ldots \ldots .\end{array}$ & $\begin{array}{r}12.9 \\
8.7\end{array}$ & $\begin{array}{r}108.8 \\
92.5\end{array}$ & $\begin{array}{l}72.9 \\
64.2\end{array}$ & $\begin{array}{l}46.3 \\
26.1\end{array}$ & $\begin{array}{l}76.2 \\
32.7\end{array}$ & $\begin{array}{r}10.9 \\
5.4\end{array}$ & $\begin{array}{r}117.1 \\
56.6\end{array}$ & $\begin{array}{r}157.9 \\
47.0\end{array}$ \\
\hline $\begin{array}{l}\text { Current work status of head } \\
\text { Working for someone else } \ldots \ldots \\
\text { Self-employed } \ldots \ldots \ldots \ldots \ldots \\
\text { Retired } \ldots \ldots \ldots \ldots \ldots \ldots \\
\text { Other not working } \ldots \ldots \ldots \ldots \ldots\end{array}$ & $\begin{array}{r}12.2 \\
16.8 \\
9.3 \\
7.8\end{array}$ & $\begin{array}{r}106.7 \\
158.9 \\
96.9 \\
98.0\end{array}$ & $\begin{array}{r}54.4 \\
92.5 \\
108.8 \\
70.3\end{array}$ & $\begin{array}{r}26.1 \\
87.1 \\
54.4 \\
114.3\end{array}$ & $\begin{array}{r}32.7 \\
108.8 \\
54.4 \\
42.5\end{array}$ & $\begin{array}{r}7.6 \\
54.4 \\
10.9 \\
6.2\end{array}$ & $\begin{array}{r}97.5 \\
275.5 \\
106.5 \\
31.0\end{array}$ & $\begin{array}{r}122.0 \\
358.3 \\
146.4 \\
19.5\end{array}$ \\
\hline $\begin{array}{l}\text { Housing status } \\
\text { Owner } \ldots \ldots \ldots \ldots \ldots \ldots \ldots \ldots \ldots \\
\text { Renter or other } \ldots \ldots \ldots \ldots \ldots \ldots\end{array}$ & $\begin{array}{r}14.4 \\
6.7\end{array}$ & $\begin{array}{c}108.8 \\
\ldots\end{array}$ & $\begin{array}{l}70.8 \\
70.3\end{array}$ & $\begin{array}{l}49.0 \\
16.3\end{array}$ & $\begin{array}{l}81.6 \\
33.7\end{array}$ & $\begin{array}{r}14.2 \\
5.4\end{array}$ & $\begin{array}{r}142.0 \\
7.8\end{array}$ & $\begin{array}{r}210.4 \\
12.7\end{array}$ \\
\hline 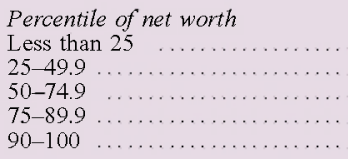 & $\begin{array}{r}5.4 \\
9.3 \\
13.7 \\
16.9 \\
25.4\end{array}$ & $\begin{array}{r}43.5 \\
65.3 \\
103.4 \\
152.4 \\
272.1\end{array}$ & $\begin{array}{r}* \\
40.8 \\
38.1 \\
87.1 \\
163.3\end{array}$ & $\begin{array}{r}* \\
10.9 \\
25.0 \\
49.0 \\
130.6\end{array}$ & $\begin{array}{r}3.8 \\
13.1 \\
43.5 \\
95.2 \\
326.5\end{array}$ & $\begin{array}{r}1.1 \\
5.4 \\
9.5 \\
16.3 \\
59.9\end{array}$ & $\begin{array}{r}7.0 \\
56.2 \\
126.9 \\
237.8 \\
563.5\end{array}$ & $\begin{array}{r}6.4 \\
66.2 \\
180.0 \\
394.4 \\
1,060.2\end{array}$ \\
\hline
\end{tabular}


8.-Continued

B. 2001 Survey of Consumer Finances

\begin{tabular}{|c|c|c|c|c|c|c|c|c|}
\hline $\begin{array}{c}\text { Familv } \\
\text { characteristic }\end{array}$ & Vehicles & $\begin{array}{l}\text { Primary } \\
\text { residence }\end{array}$ & $\begin{array}{l}\text { Other } \\
\text { residential } \\
\text { property }\end{array}$ & $\begin{array}{c}\text { Equity in } \\
\text { nonresidential } \\
\text { propertv }\end{array}$ & $\begin{array}{l}\text { Business } \\
\text { equity }\end{array}$ & Other & $\begin{array}{l}\text { Any } \\
\text { nonfinancial } \\
\text { asset }\end{array}$ & $\begin{array}{l}\text { Anv } \\
\text { asset }\end{array}$ \\
\hline & \multicolumn{8}{|c|}{ F'ercentage of families holting asset } \\
\hline All families & 84.8 & 67.7 & 11.3 & 8.3 & 11.8 & 7.6 & 90.7 & 96.7 \\
\hline 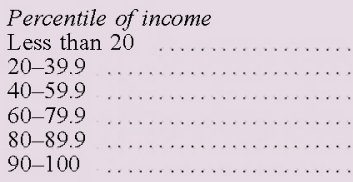 & $\begin{array}{l}56.8 \\
86.7 \\
91.6 \\
94.8 \\
95.4 \\
92.8\end{array}$ & $\begin{array}{l}40.6 \\
57.3 \\
66.0 \\
81.8 \\
90.9 \\
94.4\end{array}$ & $\begin{array}{r}3.1 \\
5.4 \\
7.9 \\
14.2 \\
19.7 \\
32.8\end{array}$ & $\begin{array}{r}2.8 \\
6.7 \\
6.7 \\
7.2 \\
12.1 \\
23.9\end{array}$ & $\begin{array}{r}2.5 \\
7.1 \\
8.8 \\
12.0 \\
18.7 \\
38.9\end{array}$ & $\begin{array}{r}2.9 \\
6.1 \\
6.2 \\
8.9 \\
9.4 \\
18.0\end{array}$ & $\begin{array}{l}67.7 \\
93.1 \\
95.6 \\
97.8 \\
99.4 \\
99.5\end{array}$ & $\begin{array}{r}85.3 \\
98.3 \\
99.8 \\
100.0 \\
100.0 \\
100.0\end{array}$ \\
\hline 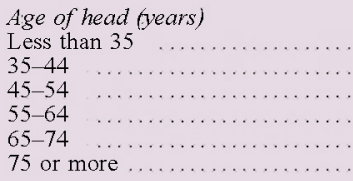 & $\begin{array}{l}78.8 \\
88.9 \\
90.5 \\
90.7 \\
81.3 \\
73.9\end{array}$ & $\begin{array}{l}39.9 \\
67.8 \\
76.2 \\
83.2 \\
82.5 \\
76.2\end{array}$ & $\begin{array}{r}3.4 \\
9.2 \\
14.7 \\
18.3 \\
13.7 \\
15.2\end{array}$ & $\begin{array}{r}2.8 \\
7.6 \\
10.0 \\
12.3 \\
12.9 \\
8.3\end{array}$ & $\begin{array}{r}7.0 \\
14.2 \\
17.1 \\
15.6 \\
11.6 \\
2.4\end{array}$ & $\begin{array}{l}6.9 \\
8.0 \\
7.2 \\
7.9 \\
9.7 \\
6.2\end{array}$ & $\begin{array}{l}83.0 \\
93.2 \\
95.2 \\
95.4 \\
91.6 \\
86.4\end{array}$ & $\begin{array}{l}93.1 \\
97.4 \\
98.1 \\
98.2 \\
97.1 \\
97.8\end{array}$ \\
\hline $\begin{array}{l}\text { Race or ethnicity of respondent } \\
\text { White non-Hispanic } \\
\text { Nonwhite or Hispanic } \ldots \ldots \ldots \ldots\end{array}$ & $\begin{array}{l}89.1 \\
70.9\end{array}$ & $\begin{array}{l}74.1 \\
47.0\end{array}$ & $\begin{array}{r}12.9 \\
6.4\end{array}$ & $\begin{array}{l}9.6 \\
4.1\end{array}$ & $\begin{array}{r}13.9 \\
5.1\end{array}$ & $\begin{array}{l}9.0 \\
2.9\end{array}$ & $\begin{array}{l}94.7 \\
77.9\end{array}$ & $\begin{array}{l}99.0 \\
89.4\end{array}$ \\
\hline $\begin{array}{l}\text { Current work status of head } \\
\text { Working for someone else } \ldots \ldots \\
\text { Self-employed } \ldots \ldots \ldots \ldots \ldots \\
\text { Retired } \ldots \ldots \ldots \ldots \ldots \\
\text { Other not working } \ldots \ldots \ldots \ldots \ldots\end{array}$ & $\begin{array}{l}88.5 \\
88.6 \\
77.1 \\
64.0\end{array}$ & $\begin{array}{l}64.7 \\
80.3 \\
73.9 \\
43.4\end{array}$ & $\begin{array}{r}10.0 \\
19.5 \\
12.0 \\
4.8\end{array}$ & $\begin{array}{r}6.7 \\
18.1 \\
8.2 \\
3.8\end{array}$ & $\begin{array}{r}6.1 \\
60.8 \\
3.3 \\
5.7\end{array}$ & $\begin{array}{r}7.4 \\
14.1 \\
5.4 \\
*\end{array}$ & $\begin{array}{l}92.5 \\
97.1 \\
86.7 \\
70.5\end{array}$ & $\begin{array}{l}97.8 \\
98.4 \\
95.7 \\
82.3\end{array}$ \\
\hline $\begin{array}{l}\text { Housing status } \\
\text { Owner } \ldots \ldots \ldots \ldots \ldots \ldots \ldots \ldots \\
\text { Renter or other } \ldots \ldots \ldots \ldots \ldots \ldots\end{array}$ & $\begin{array}{l}92.2 \\
69.3\end{array}$ & 100.0 & $\begin{array}{r}14.9 \\
3.9\end{array}$ & $\begin{array}{r}11.0 \\
2.6\end{array}$ & $\begin{array}{r}15.5 \\
4.2\end{array}$ & $\begin{array}{l}8.7 \\
5.1\end{array}$ & $\begin{array}{r}100.0 \\
71.3\end{array}$ & $\begin{array}{r}100.0 \\
89.7\end{array}$ \\
\hline 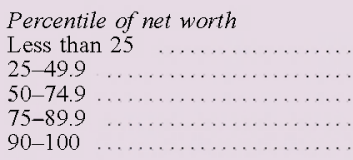 & $\begin{array}{l}64.8 \\
86.8 \\
94.1 \\
93.1 \\
94.1\end{array}$ & $\begin{array}{l}14.3 \\
69.6 \\
91.4 \\
95.1 \\
95.8\end{array}$ & $\begin{array}{r}* \\
4.5 \\
12.6 \\
19.6 \\
39.0\end{array}$ & $\begin{array}{r}* \\
3.6 \\
8.1 \\
15.4 \\
30.1\end{array}$ & $\begin{array}{r}1.2 \\
4.0 \\
11.5 \\
22.5 \\
42.8\end{array}$ & $\begin{array}{r}3.2 \\
5.1 \\
6.6 \\
10.5 \\
22.8\end{array}$ & $\begin{array}{l}68.2 \\
96.3 \\
98.7 \\
99.6 \\
99.7\end{array}$ & $\begin{array}{r}86.7 \\
100.0 \\
100.0 \\
100.0 \\
100.0\end{array}$ \\
\hline & \multicolumn{8}{|c|}{ 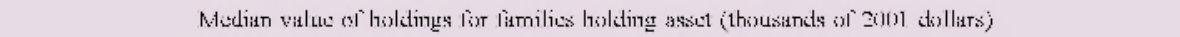 } \\
\hline All families .............. & 13.5 & 122.0 & 80.0 & 49.0 & 100.0 & 12.0 & 113.2 & 147.4 \\
\hline 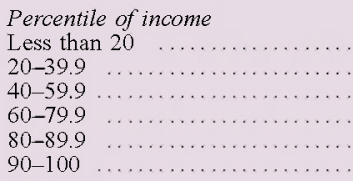 & $\begin{array}{r}5.3 \\
8.4 \\
12.6 \\
17.6 \\
22.7 \\
30.0\end{array}$ & $\begin{array}{r}65.0 \\
80.0 \\
95.0 \\
130.0 \\
175.0 \\
300.0\end{array}$ & $\begin{array}{r}25.0 \\
75.0 \\
50.0 \\
70.0 \\
62.5 \\
200.0\end{array}$ & $\begin{array}{r}32.5 \\
30.0 \\
30.0 \\
49.5 \\
46.0 \\
146.2\end{array}$ & $\begin{array}{r}56.3 \\
35.0 \\
61.7 \\
62.5 \\
100.0 \\
268.3\end{array}$ & $\begin{array}{r}6.0 \\
6.0 \\
10.0 \\
10.0 \\
20.0 \\
50.0\end{array}$ & $\begin{array}{r}34.3 \\
57.0 \\
92.2 \\
151.6 \\
224.6 \\
479.5\end{array}$ & $\begin{array}{r}24.9 \\
67.2 \\
115.0 \\
230.0 \\
377.1 \\
1,009.4\end{array}$ \\
\hline 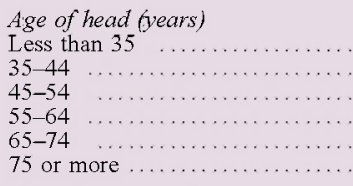 & $\begin{array}{r}11.3 \\
14.8 \\
15.7 \\
15.1 \\
13.6 \\
8.8\end{array}$ & $\begin{array}{r}95.0 \\
125.0 \\
135.0 \\
130.0 \\
129.0 \\
111.0\end{array}$ & $\begin{array}{r}75.0 \\
75.0 \\
65.0 \\
80.0 \\
145.0 \\
80.0\end{array}$ & $\begin{array}{l}33.3 \\
39.5 \\
56.4 \\
78.5 \\
50.0 \\
28.0\end{array}$ & $\begin{array}{r}50.0 \\
100.0 \\
102.0 \\
100.0 \\
100.0 \\
510.9\end{array}$ & $\begin{array}{r}10.0 \\
9.0 \\
11.0 \\
30.0 \\
20.0 \\
15.0\end{array}$ & $\begin{array}{r}30.5 \\
117.8 \\
140.3 \\
147.9 \\
149.2 \\
122.6\end{array}$ & $\begin{array}{r}39.4 \\
157.6 \\
211.6 \\
226.3 \\
214.6 \\
169.6\end{array}$ \\
\hline $\begin{array}{l}\text { Race or ethnicity of respondent } \\
\text { White non-Hispanic } \ldots \ldots \ldots \ldots \\
\text { Nonwhite or Hispanic } \quad \ldots \ldots \ldots \ldots\end{array}$ & $\begin{array}{l}14.6 \\
10.0\end{array}$ & $\begin{array}{r}130.0 \\
92.0\end{array}$ & $\begin{array}{l}80.0 \\
60.0\end{array}$ & $\begin{array}{l}50.0 \\
22.5\end{array}$ & $\begin{array}{r}100.0 \\
50.0\end{array}$ & $\begin{array}{r}15.0 \\
5.0\end{array}$ & $\begin{array}{r}131.4 \\
58.2\end{array}$ & $\begin{array}{r}183.9 \\
56.8\end{array}$ \\
\hline 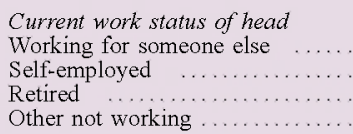 & $\begin{array}{l}13.7 \\
19.2 \\
10.1 \\
10.2\end{array}$ & $\begin{array}{l}120.0 \\
200.0 \\
100.0 \\
100.0\end{array}$ & $\begin{array}{r}70.0 \\
150.0 \\
85.0 \\
110.0\end{array}$ & $\begin{array}{r}36.8 \\
100.0 \\
58.0 \\
33.0\end{array}$ & $\begin{array}{r}50.0 \\
126.0 \\
65.5 \\
110.0\end{array}$ & $\begin{array}{c}10.0 \\
30.0 \\
20.0 \\
\approx\end{array}$ & $\begin{array}{r}101.8 \\
335.0 \\
105.8 \\
71.1\end{array}$ & $\begin{array}{r}129.0 \\
439.2 \\
143.4 \\
41.4\end{array}$ \\
\hline $\begin{array}{l}\text { Housing status } \\
\text { Owner } \ldots \ldots \ldots \ldots \ldots \ldots \ldots \ldots \ldots \ldots \ldots \ldots \\
\text { Renter or other } \ldots \ldots \ldots \ldots \ldots \ldots \ldots\end{array}$ & $\begin{array}{r}16.2 \\
7.6\end{array}$ & 122.0 & $\begin{array}{l}80.0 \\
60.0\end{array}$ & $\begin{array}{l}50.0 \\
32.5\end{array}$ & $\begin{array}{r}105.0 \\
35.0\end{array}$ & $\begin{array}{r}15.0 \\
6.0\end{array}$ & $\begin{array}{r}156.9 \\
8.9\end{array}$ & $\begin{array}{r}240.1 \\
13.4\end{array}$ \\
\hline 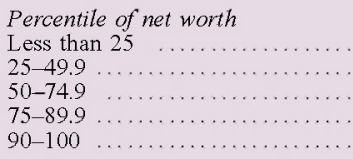 & $\begin{array}{r}6.3 \\
11.8 \\
15.3 \\
19.0 \\
28.8\end{array}$ & $\begin{array}{r}49.5 \\
70.0 \\
120.0 \\
200.0 \\
350.0\end{array}$ & $\begin{array}{r}x \\
24.0 \\
50.0 \\
80.0 \\
210.0\end{array}$ & $\begin{array}{r}\% \\
9.0 \\
25.0 \\
52.3 \\
211.7\end{array}$ & $\begin{array}{r}10.0 \\
15.0 \\
50.0 \\
120.0 \\
500.0\end{array}$ & $\begin{array}{r}4.0 \\
10.0 \\
10.0 \\
18.0 \\
40.0\end{array}$ & $\begin{array}{r}8.2 \\
62.6 \\
144.8 \\
281.8 \\
712.5\end{array}$ & $\begin{array}{r}8.2 \\
75.1 \\
215.2 \\
508.5 \\
1,438.1\end{array}$ \\
\hline
\end{tabular}

Note. See note to table 1 .

*Ten or fewer observations.

Not applicable. 
The median holding of net business equity for those having a business interest jumped 53.1 percent from 1998 to 2001, about twice the rate of increase in median holdings of all types of publicly traded corporate equities. Almost every demographic group showed an increase, many of which were substantial.

The SCF classifies privately owned business interests into those in which the family has an active management role and those in which it does not. Of families having any business interests in 2001, 87.8 percent had only an active role and 9.0 percent had only a non-active role; 3.2 percent had interests in both types (not shown in tables). In terms of assets, the actively managed interests account for 89.0 percent of total privately owned business interests. Although some families have more than one business that they actively manage, the median number is 1 , and the total value of all primary actively managed businesses accounts for 81.0 percent of the value of all actively managed businesses. ${ }^{\underline{ } x}$ The most common organizational form for the primary actively managed business is a sole proprietorship, and the vast majority of primary actively managed businesses operate in an industry other than manufacturing; the median number of employees is two. These figures are little changed since 1998.

\section{Other Nonfinancial Assets}

Ownership of the remaining nonfinancial assets (tangible items including artwork, jewelry, precious metals, antiques, hobby equipment, and collectibles)

22. Families with more than one business are asked to report which business is most important; that business is designated as the primary one. declined 0.9 percent during the recent three-year period, to 7.6 percent of families. In general, ownership is relatively more common among the highest income and wealth groups and among families headed by self-employed persons. Ownership declined for most demographic groups between 1998 and 2001. However, the group for which the ownership rate was already the highest, that is, families with net worth in the highest 10 percent of the distribution, saw their ownership rate rise 4 percentage points. The overall median value of these assets rose 10.1 percent. Although increases were common across demographic groups, the highest wealth group saw a sizable decline; the decline suggests that the group's rise in rate of ownership resulted from the addition of relatively small holdings.

\section{Unrealized Capital Gains}

Changes in the values of assets such as stock, real estate, and businesses are a key determinant of changes in families' net worth. Unrealized gains are increases in the value of assets that are yet to be sold. To obtain information on this part of net worth, the survey asks about changes in value from the time of purchase for certain key assets-publicly traded stocks, mutual funds, the primary residence, other real estate, and businesses. ${ }^{2.5}$ The median unrealized capital gain in these assets over the 1998-2001 period moved up 29.3 percent, and the mean moved up 24.7 percent (table 9). Both measures were well above their 1992 levels. The rise in unrealized gains

23. The survey does not collect information on capital gains for every asset. Most notably, it does not collect such information for retirement accounts.

9. Family holdings of unrealized capital gains, by selected characteristics of families, 1992, 1995, 1998, and 2001 surveys Thousands of 2001 dollars

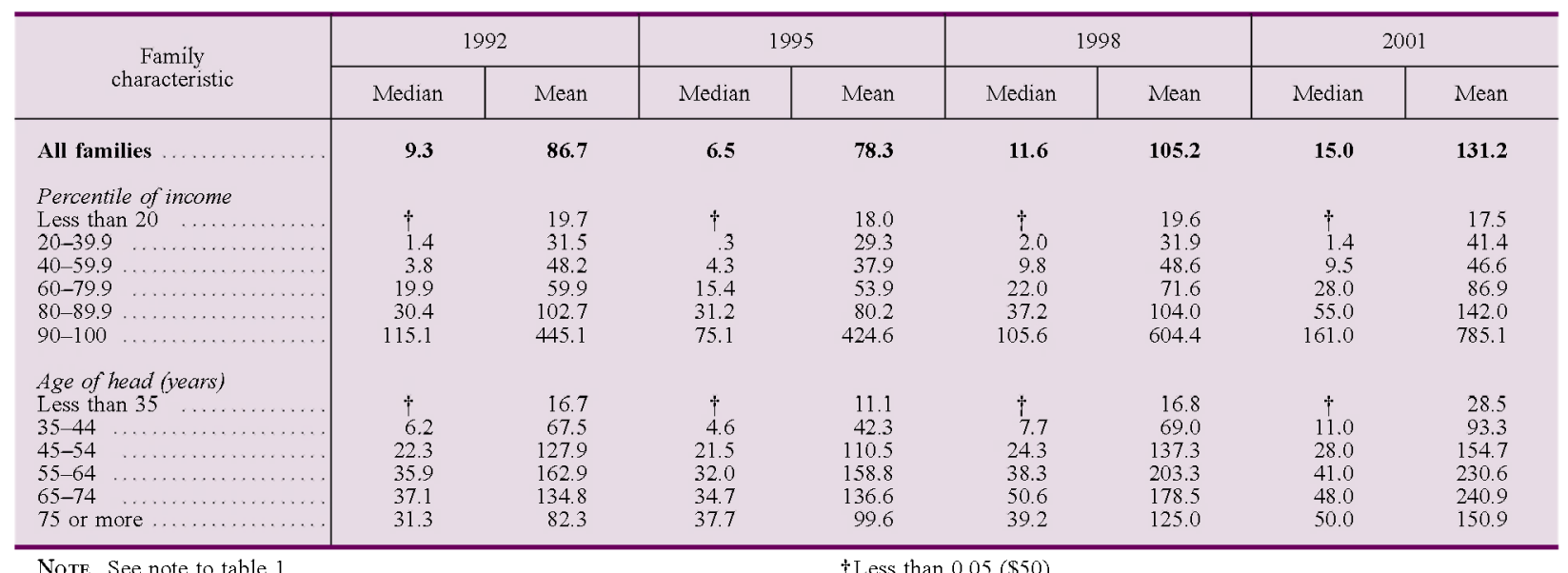

Note. See note to table 1

tLess than $0.05(\$ 50)$ 
reflects strong asset appreciation over the period as well as the relative illiquidity of real estate and businesses,

\section{LIABILITIES}

Liabilities and assets both grew substantially from 1998 to 2001, but assets grew more rapidly overall. As a consequence, the ratio of family debts to assets (the leverage ratio) fell from 14.3 percent to 12.1 percent (table 10). The ratio measured by the survey had been little changed between 1992 and 1998. The 2001 level of the leverage ratio is marginally lower than the 12.4 percent level registered in the 1989 survey. Home-secured debt accounted for 75.1 percent of total family debt in 2001, up 3.8 percentage points from 1998 .

\section{Families' Holdings of Debt}

After a decline of almost 1, 2 percentage point between 1995 and 1998 in the share of families with any type of debt (not shown in tables), the share rebounded 1 percentage point in 2001 , to 75.1 percent of all families (table 11). Borrowing is more prevalent among families in the income and wealth groups above the lowest and in age groups below 65 . Over the 1998-2001 period, most demographic groups saw an increase in the proportion of families borrowing. However, the proportion of families in the highest wealth group that were indebted declined notably.

The overall median value of total outstanding debt for families that had any rose 9.6 percent from 1998 to 2001. Across demographic groups, median debt rises with income and wealth; it rises and then declines with age. The decline among older age groups is driven in large part by the paying off of mortgages on primary residences. The median

10. Amount of debt of all families, distributed by type of debt, 1992, 1995, 1998, and 2001 surveys Percent

\begin{tabular}{|c|c|c|c|c|}
\hline Type of debt & 1992 & 1995 & 1998 & 2001 \\
\hline Home-secured debt & 72.0 & 73.1 & 71.3 & 75.1 \\
\hline Other residential property & 10.4 & 7.7 & 7.7 & 6.4 \\
\hline Installment loans.... . & 11.3 & 11.9 & 13.0 & 12.3 \\
\hline Other lines of credit & 8 & 6 & 3 & .5 \\
\hline Credit card balances & 3.2 & 3.9 & 3.9 & 3.4 \\
\hline Other $\ldots \ldots \ldots \ldots$ & 2.3 & 2.8 & 3.7 & 2.3 \\
\hline Total & 100 & $100^{\circ}$ & 100 & 100 \\
\hline \multicolumn{5}{|l|}{ Мemo } \\
\hline $\begin{array}{c}\text { Debt as a percentage } \\
\text { of total assets }\end{array}$ & 14.5 & 14.6 & 14.3 & 12.1 \\
\hline
\end{tabular}

amount of debt in the oldest age group dropped during the 1998-2001 period, a decline that partially reversed a jump seen in the $1995-98$ period. In the most recent three-year period, median debt rose for most other demographic groups. Over work-status groups, the median of only the retired group fell. The median rose substantially for all wealth groups except the lowest one.

\section{Mortgages and Other Borrowing on the Primary Residence}

Between 1998 and 2001, the proportion of families with home-secured debt rose 1.5 percentage points, to 44.6 percent. $^{24}$ The increase continues a trend that has been observed in the survey since 1992. Use of home-secured debt rose for most demographic groups in the recent period; groups with a notable decrease were families headed by persons aged 75 and older, the highest wealth group, and families headed by self-employed persons.

Overall, the median amount of home-secured debt rose 3.7 percent from 1998 to 2001. Increases were most marked for families headed by persons aged 65 and older, families headed by self-employed persons, and families that had net worth in the highest 10 percent of the distribution. For the first two of these groups, the accompanying decline in ownership suggests that those with relatively low levels of such debt were disproportionately represented in the decline in ownership. Despite an increase in the proportion of nonwhite or Hispanic families using home-secured debt, the median amount owed by this group declined; in light of relatively little change in either the ownership rate or the median value of principal residences, the decline in the median amount owed may reflect largely the paying down of existing mortgages.

The rising values of houses over this period outpaced the attendant increases in home-secured debt and raised the typical amount of home equity held by families (not shown in tables). Median home equity among those with home-secured debt rose from $\$ 53,300$ in 1998 to $\$ 58,100$ in 2001 , a 9.0 percent increase. Among those with such debt, the median ratio of home-secured debt to the value of the principal residence fell from 58.8 percent in 1998 to 56.0 percent in 2001 ; at the same time, a surveybased estimate of the aggregate ratio of debt to home values fell from 36.5 percent to 33.5 percent.

\footnotetext{
24. Home-secured debt consists of first and second mortgages and home equity loans and lines of credit secured by the primary residence.
} 
11. Family holdings of debt, by selected characteristics of families and type of debt, 1998 and 2001 surveys A. 1998 Survey of Consumer Finances

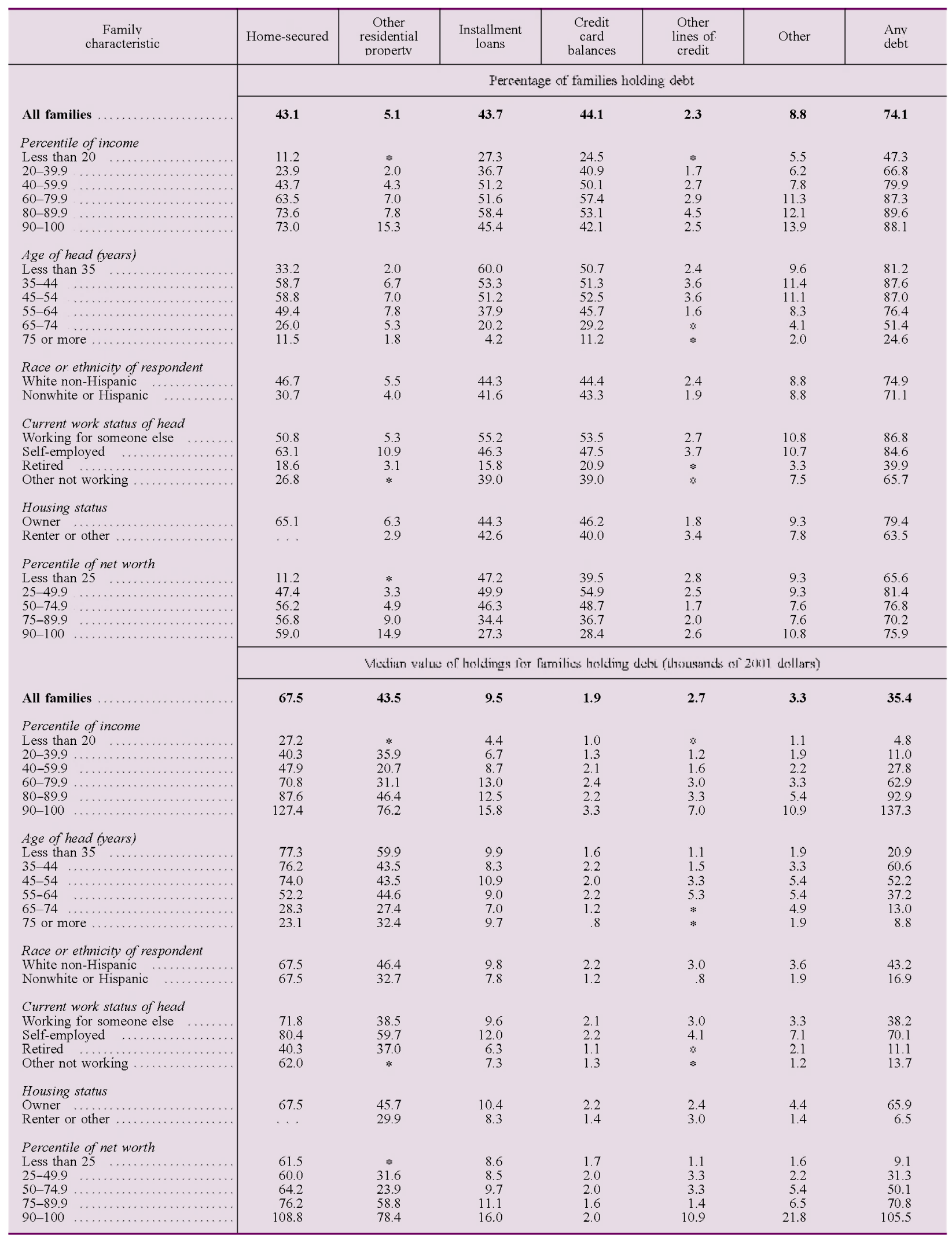


11. Continued

B. 2001 Survey of Consumer Finances

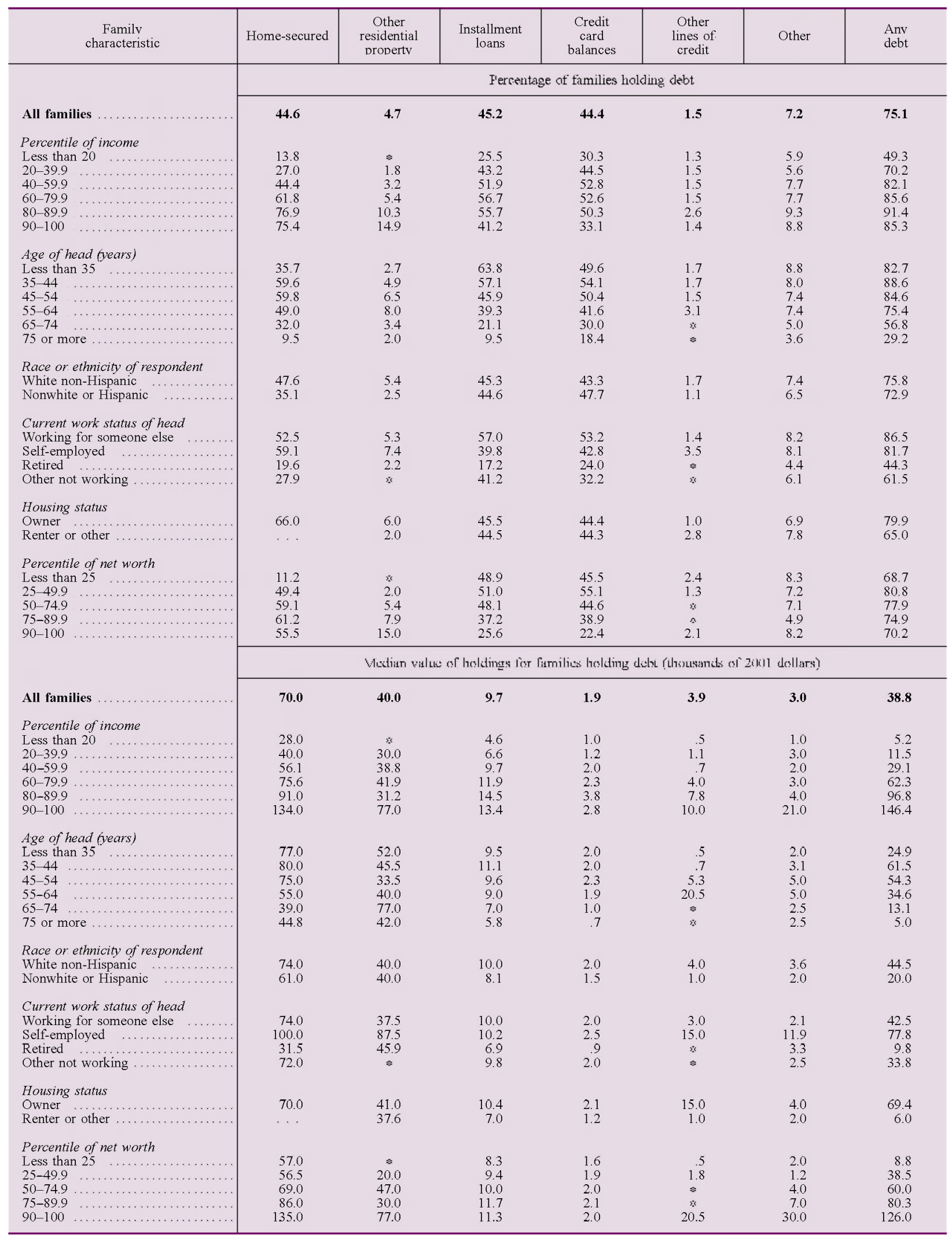

Note. See note to table 1.

*Ten or fewer observations.

Not applicable 
Although home purchase remains the main purpose of home-secured debt, the incentive to use such borrowing for other purposes has been higher since the Tax Reform Act of 1986, which phased out the deductibility of interest payments on most debt other than that secured by a primary residence. In addition, declining mortgage interest rates since 1998 provided many families the incentive to refinance existing mortgages. By refinancing for more than the existing balance, many families were able to obtain funds for other purposes.

The survey provides some evidence of such borrowing. Families that refinanced a main mortgage were asked whether additional funds were obtained, and if so, how the funds were used; families that carried a second mortgage, home equity loan, or home equity line of credit were asked the purpose of the borrowing. Families that simply chose to take out larger initial mortgages to free up funds to spend for other purchases would not be captured by these questions. However, among families with any type of home-secured debt, the available data suggest that the proportion who used such borrowing for a purpose other than just financing their home declined in the period after 1998. In that year, the proportion of families with such borrowing was 33.6 percent, and in 2001 the figure was 32.1 percent; however, the 2001 level is substantially above the 1995 level of 22.2 percent. ${ }^{25}$

Home equity lines of credit are a widely advertised source of tax-preferred borrowing. Among homeowners, the proportion of families with a home equity line edged up 0.4 percentage point, to 14.9 percent in 2001; the proportion actually drawing on such lines rose 0.7 percentage point, to 10.6 percent.

\section{Borrowing on Other Residential Real Estate}

The decline in ownership of other residential real estate was accompanied by a marginal decline in the proportion of families with borrowings for such real estate, from 5.1 percent in 1998 to 4.7 percent in 2001. As with the ownership of such property, the associated borrowing is most prevalent among families with relatively high income or wealth. Over the period, the use of such debt declined for most demographic groups. At the same time, the overall median amount of such debt fell 8.0 percent, but the changes in the median across demographic groups were mixed.

25. Appropriate data do not exist in the survey to construct this measure for earlier years.

\section{Installment Borrowing}

The use of installment borrowing is broadly distributed, with notably lower use only in the lowest and highest income groups, the highest wealth group, and families headed by retired persons or persons aged 65 and older. ${ }^{26}$ From 1998 to 2001, overall use of installment borrowing rose 1.5 percentage points, to 45.2 percent, an increase reflecting, in part, a rise in the percent of families with vehicle loans. Between 1992 and 1998, the use of installment borrowing had been declining, and the 2001 usage is still below that of 1992. By income group, the increase over the recent three-year period was seen only for the broad center of the distribution, that is, for families with incomes in the 20th through 80th percentiles. Over the same period, the median amount owed went up only 2.1 percent, and changes in the median across groups were mixed.

\section{Borrowing on Credit Cards}

The use of credit cards for borrowing is also widespread but is notably lower among the highest and lowest income groups and among families headed by persons aged 65 or older or by persons who are not working. ${ }^{27}$ From 1998 to 2001 , the proportion of families using such borrowing edged up 0.3 percentage point, to 44.4 percent; this small rise breaks a decline of more than 3 percentage points in the 1995-98 period.

Despite the marginal overall change in usage during the recent three-year period, usage among groups shifted more noticeably. Across income groups, usage rose for families with incomes below the 60th percentile, and it fell for groups above that point; similarly, declines for homeowners and white non-Hispanic families were offset by increases for their complementary sets of families. The median balance in 1998 for those that had credit card debt- $\$ 1,900$-was unchanged in 2001. Changes in the median, which were mixed and generally small across groups, were most notable for families with incomes in the 80th to 90 th percentiles and those with net worth in the 75th to 90 th percentiles.

26. The term "installment borrowing" in this article describes consumer loans that typically have fixed payments and a fixed term. Examples are automobile loans, student loans, and loans for furniture, appliances, and other durable goods.

27. Credit cards consist of bank-type cards (such as Visa, MasterCard, Discover, and Optima), store cards or charge accounts, gasoline company cards, so-called travel and entertainment cards (such as American Express and Diners Club), and other credit cards. In the survey, the amount borrowed on such cards is the amount remaining after the most recent bill was paid. 
Although the proportion of families using credit card borrowing was little changed, the proportion of families having some type of credit card rose 3.7 percentage points from 1998 , to 76.2 percent of families in 2001 (not shown in tables). Over the same period, the proportion of families with cards changed as follows for the various card types (not shown in tables): bank-type cards, up 5.2 percentage points, to 72.7 percent; travel and entertainment cards, up 1.4 percentage points, to 10.5 percent; store cards, down 4.8 percentage points, to 45.2 percent; and gasoline company cards, down 3.1 percentage points to 16.1 percent. Ownership rates for other cards and accounts were relatively small and changed little.

As the most widely held type of card, the banktype card holds particular importance in any examination of family finances. The ownership rate of such cards rose over the recent three-year period, but the proportion of families with such cards who carried a balance fell 1 percentage point, to 53.7 percent in 2001. The proportion of families with such cards that reported that they usually pay off their credit card bills in full each month rose 1.5 percentage points, to 55.3 percent. The median charge for the month preceding the interview on all bank-type cards held by the family was unchanged at $\$ 200$.

\section{Borrowing on Other Lines of Credit}

The use of lines of credit other than home equity lines is not common, and from 1998 to 2001 it fell 0.8 percentage point, to 1.5 percent of families. In addition, the proportion of families who had such lines fell more, from 3.9 percent to 2.7 percent (not shown in tables). At the same time, however, typical balances for those that had them rose 44.4 percent, to $\$ 3,900$.

\section{Other Debt}

From 1998 to 2001, the proportion of families that incurred other types of debt fell 1.6 percentage points, to 7.2 percent. ${ }^{28}$ The use of other debt is spread broadly across demographic groups, but rates of use are notably lower for families headed by those who are retired or are 65 years of age and older. The decline in overall use appears to have been driven largely by a decline in borrowing against whole life

28. Other borrowing comprises loans on insurance policies, loans against pension accounts, borrowing on margin accounts, and a residual category for all loans not explicitly referenced elsewhere. insurance policies, which the survey indicates became less prevalent over this period; the other components of the use of this type of debt were little changed (not shown in tables). The median amount of other debt for those who had any fell 9.1 percent, to $\$ 3,000$.

\section{Reasons for Borrowing}

The SCF provides information on the reasons that families borrow money (table 12). One subtle problem with the use of these data is that, even though money is borrowed for a particular purpose, it may be used to offset some other use of funds. For example, a family may have sufficient funds to purchase a home without using a mortgage but may instead choose to finance the purchase to free existing funds for another purpose. Thus, trends in the data can only suggest the underlying use of funds by families.

The survey does not collect exhaustive detail on the use of borrowed funds. In the case of credit cards, it was deemed impractical to ask about the purposes of borrowing that might well be heterogeneous for individual families. For the analysis here, all credit card debt is included in the category "goods and services." All funds owed on a first mortgage on a principal residence are assumed to have been used for the purchase of the home, even when the loan has been refinanced. Because the surveys before 1998 did not collect information on the uses of funds borrowed from pension accounts, the table reports borrowing from pension accounts as a separate category, unclassified as to purpose.

The data indicate that the proportion of total family borrowing attributable to home purchase went up 3 percentage points between 1998 and 2001, to 70.7 percent, a peak for the years shown. The increase was offset by declines in other categories, including other residential property and investments.

12. Amount of debt of all families, distributed by purpose of debt, 1992, 1995, 1998, and 2001 surveys

Percent

\begin{tabular}{|c|c|c|c|c|}
\hline Purbose of debt & 1992 & 1995 & 1998 & 2001 \\
\hline Home purchase & 67.2 & 70.3 & 67.7 & 70.7 \\
\hline Home improvement & 2.5 & 2.0 & 2.1 & 1.9 \\
\hline Other residential property & 10.9 & 8.2 & 7.9 & 6.6 \\
\hline Investments excluding real estate. & 1.8 & 1.0 & 3.3 & 2.8 \\
\hline Vehicles $\quad . \ldots \ldots \ldots \ldots \ldots \ldots$ & 7.0 & 7.6 & 7.6 & 7.8 \\
\hline Goods and services $\ldots .$. & 5.6 & 5.7 & 6.1 & 5.7 \\
\hline Education $\ldots \ldots \ldots \ldots$ & 2.8 & 2.7 & 3.4 & 3.1 \\
\hline Unclassifiable loans against & & & & \\
\hline pension accounts .... & .1 & .2 & 4 & .3 \\
\hline Other $\ldots \ldots \ldots \ldots \ldots \ldots$ & 2.1 & 2.2 & 1.5 & 1.1 \\
\hline Total $\ldots \ldots \ldots \ldots \ldots$ & 100 & 100 & 100 & 100 \\
\hline
\end{tabular}

Note. See note to table 1 
However, the treatment of first mortgages on a principal residence may cast doubt on these conclusions. Beginning with the 1995 survey, as noted in the discussion of home-secured debt, some information has been collected on the use of funds when such mortgages have been refinanced. But even for that and later surveys, the proportion of funds used for purposes other than refinancing the earlier mortgage is unknown. Nonetheless, other information suggests that the results should not be far off. Only 15.5 percent of families with mortgages in 2001 had refinanced and extracted additional home equity at some time and still had a mortgage; of those families, 43.1 percent used some part of the funds for home repairs or improvements, 31.3 percent used some part for more general purchases, 15.3 percent used some part for real estate or other investments, 6.9 percent used some part for the purchase of vehicles, and 3.5 percent used some part for education expenses (not shown in tables).

\section{Choice of Lenders}

The survey provides information on the types of lenders to which families owe money at the time of the interview (table 13). The data show two longstanding and approximately offsetting trends. The share of total family debt attributable to thrift institutions fell in each survey since before 1992, to reach 6.1 percent in 2001, a decline of 10.8 percentage points over the nine-year period. Offsetting this movement has been a concurrent rise of 10.7 percentage points in the share of debt associated with specialized mortgage or other real estate lenders, the lender type with the largest share of the total. Commercial banks account for the second largest share of

13. Amount of debt of all families, distributed by type of lending institution, 1992, 1995, 1998 , and 2001 surveys

Percent

\begin{tabular}{|c|c|c|c|c|}
\hline Tvpe of institution & 1992 & 1995 & 1998 & 2001 \\
\hline Commercial bank & 33.1 & 34.9 & 32.8 & 34.1 \\
\hline Thrift institution ${ }^{1}$ & 16.9 & 10.8 & 9.7 & 6.1 \\
\hline Credit union $\ldots$ & 4.0 & 4.5 & 4.2 & 5.5 \\
\hline Finance or loan company & 3.2 & 3.2 & 4.2 & 4.3 \\
\hline Brokerage .............. & 3.2 & 1.9 & 3.8 & 3.1 \\
\hline Mortgage or real estate lender & 27.3 & 32.8 & 35.5 & 38.0 \\
\hline Individual lender & 4.2 & 5.0 & 3.3 & 2.0 \\
\hline Other nonfinancial & 1.6 & 8 & 1.3 & 1.4 \\
\hline Government ...... & 1.9 & 1.2 & 6 & 1.1 \\
\hline Credit card and store card & 3.3 & 3.9 & 3.9 & 3.7 \\
\hline Pension account & .1 & .2 & .4 & .3 \\
\hline Other ......... & 1.1 & .7 & 3 & .5 \\
\hline Total & 100 & 100 & 100 & 100 \\
\hline
\end{tabular}

Note. See note to table 1 .

1. Savings and loan association or savings bank such lending; their proportion of debt has oscillated up and down by about 1.5 percentage points since 1992; in the most recent three-year period, it rose 1.4 percentage points. The share of lending by individuals has declined by about half since 1992 and was 2.0 percent of the total in 2001 . Other changes are smaller and without apparent trend.

In some cases, loans may have been held at the time of the interviews by institutions other than the ones that originally made the loans. Resale of loans is particularly important for mortgage debt. According to the 2001 survey, 40.9 percent of the first mortgages on primary residences were held by a lender other than the one that made the original loan, down slightly from the 43.1 figure for 1998 (not shown in tables). In dollar-weighted terms, the results are similar. Mortgages with non-originating lenders account for 43.2 percent of the outstanding balances on first mortgages for principal residences, and the figure for 1998 is 44.6 percent.

\section{Debt Burden}

As aggregate household debt reported in the Federal Reserve's flow of funds accounts has risen over the past decade, concern has been expressed that debt might become excessively burdensome to families. However, rising aggregate debt levels alone do not necessarily imply that conditions deteriorated at the level of individual families. The ability of individual families to service their loans is a function of two factors: the level of their loan payments and the income and assets they have available to meet those payments. In planning their borrowing, families make assumptions about their future ability to repay their loans. Problems may occur when events turn out to be contrary to those assumptions. If such errors of judgment were sufficiently large and prevalent, a broad pattern of default, restraint in spending, and broader financial distress in the economy might ensue.

Several factors affecting income and payments shifted over the 1998-2001 period. Interest rates, a key determinant of payments, rose but then declined into 2001. Another important determinant of payments is the term over which a loan is scheduled to be repaid; families may have opted for different terms either directly or by substituting longer-term borrowing based on home equity for loans with shorter terms. Incomes rose fairly broadly over the period, while the proportion of families with debt and the typical amount owed also rose. The net consequences of these movements on the ratio of payments to 
income can only be assessed by looking at how these factors vary together over families.

The Federal Reserve staff has constructed an aggregate-level measure of debt burden: an estimate of total scheduled loan payments (interest plus minimum repayments of principal) for all households, divided by disposable personal income. From 1998 to 2001 , the aggregate-level measure rose about 1 percentage point, to about 14 percent ${ }^{29}$

The survey data may be used to construct a similar estimate of the debt-burden ratio and to construct such an estimate for various demographic groups (table 14). The SCF-based estimate is the ratio of total debt payments for all families to total family income of all families. In contrast to the aggregatelevel estimate, the SCF-based estimate declined 1.9 percentage points over the three-year period, to 12.5 percent, after having remained fairly flat over the 1992-98 period. If total payments and incomes are computed only for families with debt, the results are similar. The SCF-based measure also declined over the recent three-year period for almost every demographic group shown; the only notable exception is families with net worth in the 75th to 90 th percentiles of the distribution, for whom the ratio rose 0.6 percentage point. ${ }^{30}$

29. A description of this series, and the data for it since 1980 , are at www.federalreserve,gov/releases/housedebt/default.htm. Movements in this ratio may say something about changes in the ability of families as a whole to increase their current consumption, either through direct purchases or through additional borrowing, but they do not necessarily imply that financial restraint moved in any particular way for individual families; to make the latter assessment, one must know the joint movements of income and payments across families.

30. The survey measure of: payments relative to income may differ from the aggregate-level measure for several reasons. First, the debt payments included in each measure are different. The aggregate-level measure includes only debts originated by depositories, finance companies, and other financial institutions, whereas the survey includes, in principle, debts from all sources.

Second, the aggregate-level measure uses a NIPA estimate of disposable personal income for the period concurrent with the estimated payments as the denominator of the ratio, whereas the survey measure uses total before-tax income reported by survey families for the preceding year; the differences in these two income measures are complex.

Third, the payments in the aggregate-level measure are estimated using a formula that entails complex assumptions about minimum payments and the distribution of loan terms at any given time; the survey measure of payments is directly asked of the survey respondents but may also include payments of taxes and insurance on real estate loans.

Fourth, because the survey measures of payments and income are based on the responses of a sample of respondents, they may be affected both by sampling error and by various types of response error. As mentioned earlier in this article, the survey income measure tracks the most comparable measure of income in the Census Bureau's Current Population Survey. Over the same time, however, the SCF shows a little less growth in the aggregate level of debt than the Federal Reserve's flow of funds accounts; timing and conceptual differences might explain some of: the difference.
The survey data also make it possible to compute measures of payment burden that are not possible with the Federal Reserve's aggregate-level estimate. In particular, the survey allows a detailed look at the spectrum of payments relative to income across all households with debts. Like the ratio of survey-based totals, the median of the ratios for individual families that had any debt declined 2.1 percentage points in the recent three-year period, to 16.0 percent. Moreover, the measure declined for virtually every group shown.

A limitation of the median ratio is that it may not be indicative of distress because it reflects the situation of only a typical family. Unless errors of judgment by both families and lenders were pervasive, one would not expect to see signs of financial distress at the median. Thus, a more compelling indicator of distress is the proportion of families with unusually large total payments relative to their incomes. From 1998 to 2001, the proportion of debtors with payments exceeding 40 percent of their incomes fell 1.8 percentage points, to 11.0 percent, a level only 0.2 percentage point above the 1992 level. Like the other two survey-based payment measures, this indicator also fell across nearly all demographic groups shown.

Other commonly used indicators of debt repayment problems are aggregate delinquency rates, that is, the number of delinquent accounts or the percentage of total balances on which payments are late. Data on these measures from various sources and for different types of credit do not give a consistent picture of changes in delinquencies over the period. ${ }^{31}$

A related measure is collected in the SCF. Families that have any debts at the time of their interview are asked whether they have been behind in any of their payments in the preceding year. This measure differs conceptually from the aggregate delinquency rates in that the survey counts multiple occasions of late

Finally, the survey measure excludes debt payments of household members who are not members of the family unit analyzed in this article.

31. Measures of the share of closed-end consumer credit outstanding on which payments are late by sixty days or more, based on data from the Call Report and from the American Bankers Association $(\mathrm{ABA})$, showed little change on a point-to-point basis between the 1998 and 2001 surveys. Data from the ABA and from the captive finance company subsidiaries of motor vehicle manufacturers on delinquency rates on automobile loans show opposite trends for the period. Several measures-based on data from the Call Report, the $A B A$, and Moody's on credit card debt in securitized pools-show an overall increase in the delinquency rate on credit card debt over the interval. Delinquency rates on mortgages, after falling for the two years after 1998, rebounded through 2001 . 
14. Ratios of debt payments to family income (aggregate and median), share of debtors with ratio above 40 percent, and share of debtors with any payment sixty days or more past due, by selected characteristics of families, $1992,1995$. 1998, and 2001 surveys

Percent

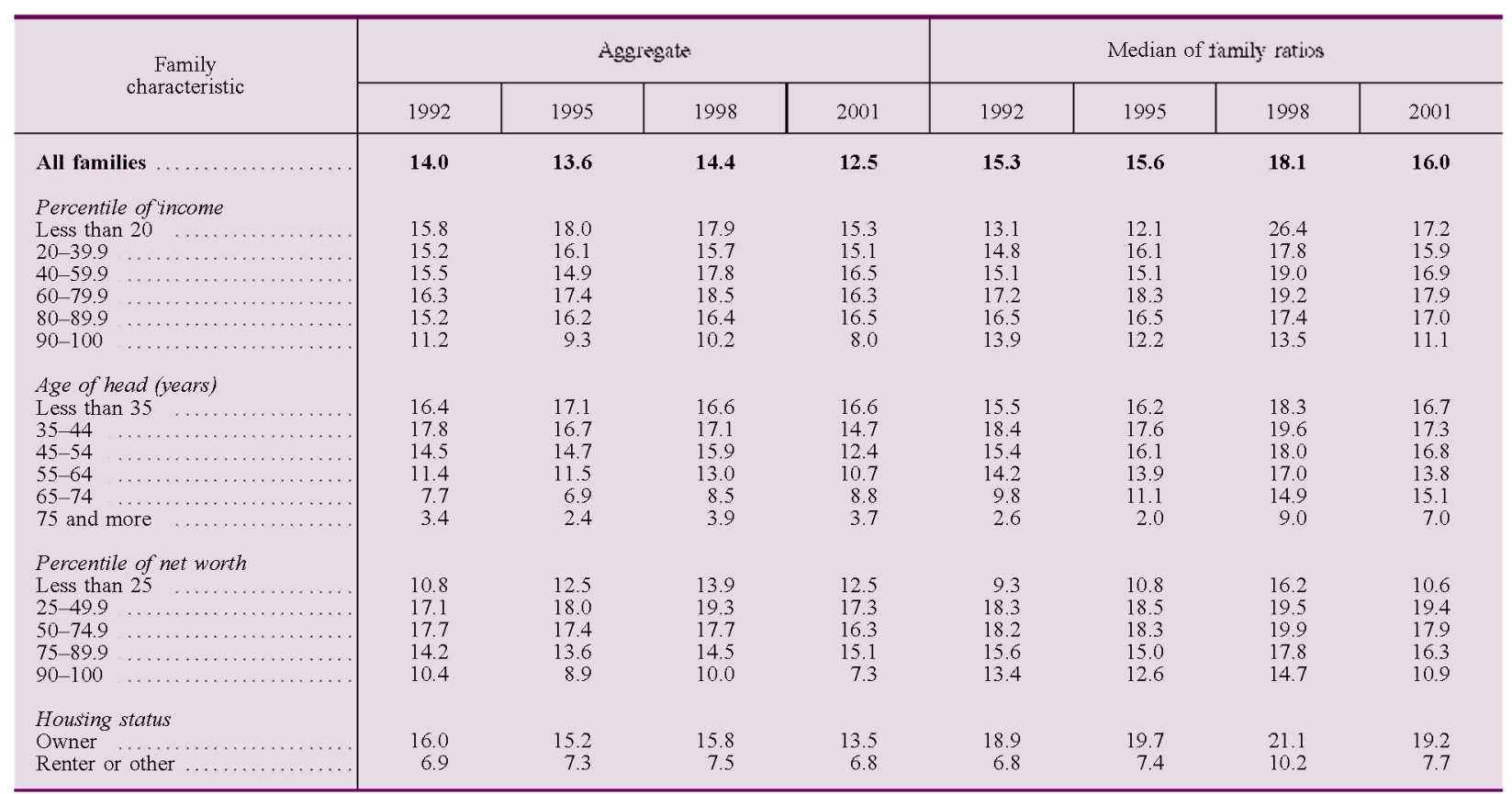

payments as one and counts families instead of balances or accounts. ${ }^{32}$. Over the 1998-2001 period, the survey shows an overall decline in the proportion of debtors who were sixty or more days late with their payments on any of their loans in the preceding year; the share of such families fell 1.1 percentage points, to 7.0 percent.

Although the measure also declined over most demographic groups, the exceptions are interesting. For families with incomes in the lowest 20 percent of the distribution, the percent late rose 0.5 percentage point; for families headed by persons aged less than 35 , it rose 0.8 percentage point; for families with net worth in the lowest 25 percent of that distribution, it rose 1.6 percentage points; and for renters it rose 1.2 percentage points. Thus, debt repayment problems appear to exist for some groups despite the apparent lack of obvious patterns in the distribution of payments relative to income for the same groups. The explanation may be the use of a lagged value of income in the ratio of payments to income; for families with late payments, income may have deteriorated subsequently.

32. In addition, the aggregate measures cover only certain loan types.

\section{SUMMARY}

The median and mean values of net worth of families as a whole grew substantially from 1998 to 2001 but not for all demographic groups distinguished in this report. Among groups defined by education of the family head, net worth rose only for the groups at the opposite extremes: families headed by persons without a high school diploma or its equivalent and families headed by persons with at least a college degree. The net worth of nonwhite or Hispanic families barely moved at the median, and the increase in the mean was notably below that of other families. Although equity markets declined further after the survey was completed, a sensitivity analysis suggests that with equity prices as low as they were in October 2002 , both median and mean family net worth still exceeded their levels in 1998.

Accounting for the various ways in which families might own publicly traded corporate equities, the share of families owning any exceeded 50 percent in 2001. At the same time, the median holding of families with equities rose more than one-fourth. Although managed assets, such as annuities, trusts, and managed investment accounts, are not owned by a large share of the population-less than 7 percent of families in $2001-a$ large increase in both the 
14.-Continued

Percent

\begin{tabular}{|c|c|c|c|c|c|c|c|c|}
\hline \multirow{2}{*}{$\begin{array}{c}\text { Family } \\
\text { characteristic }\end{array}$} & \multicolumn{4}{|c|}{ Familias with ratios greater than $4(1$ percent } & \multicolumn{4}{|c|}{ Families wit 1 any payment past tue sixty tays or more } \\
\hline & 1992 & 1995 & 1998 & 2001 & 1992 & 1995 & 1998 & 2001 \\
\hline All families .... & 10.8 & 10.6 & 12.8 & 11.0 & 6.0 & 7.1 & 8.1 & 7.0 \\
\hline 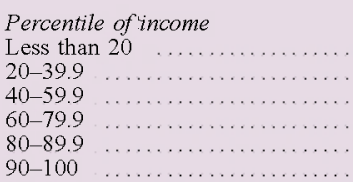 & $\begin{array}{r}26.4 \\
15.1 \\
10.1 \\
7.6 \\
2.9 \\
2.5\end{array}$ & $\begin{array}{r}26.2 \\
16.0 \\
8.1 \\
7.1 \\
4.6 \\
2.0\end{array}$ & $\begin{array}{r}28.2 \\
17.2 \\
15.3 \\
8.6 \\
3.4 \\
2.6\end{array}$ & $\begin{array}{r}27.0 \\
16.0 \\
11.7 \\
5.6 \\
3.5 \\
2.0\end{array}$ & $\begin{array}{r}11.0 \\
9.3 \\
6.9 \\
4.4 \\
1.8 \\
1.0\end{array}$ & $\begin{array}{r}10.2 \\
10.1 \\
8.7 \\
6.6 \\
2.8 \\
1.0\end{array}$ & $\begin{array}{r}12.9 \\
12.3 \\
10.0 \\
5.9 \\
3.9 \\
1.6\end{array}$ & $\begin{array}{r}13.4 \\
11.7 \\
7.9 \\
4.0 \\
2.6 \\
1.3\end{array}$ \\
\hline 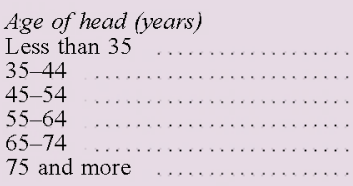 & $\begin{array}{r}10.5 \\
11.5 \\
10.0 \\
14.3 \\
7.4 \\
8.7\end{array}$ & $\begin{array}{r}11.4 \\
9.3 \\
10.6 \\
14.4 \\
7.8 \\
7.4\end{array}$ & $\begin{array}{l}11.8 \\
11.8 \\
11.5 \\
13.9 \\
17.5 \\
20.9\end{array}$ & $\begin{array}{r}10.8 \\
9.4 \\
10.9 \\
12.2 \\
13.9 \\
14.3\end{array}$ & $\begin{array}{l}8.3 \\
6.8 \\
5.4 \\
4.7 \\
1.0 \\
1.8\end{array}$ & $\begin{array}{l}8.7 \\
7.7 \\
7.4 \\
3.2 \\
5.3 \\
5.4\end{array}$ & $\begin{array}{r}11.1 \\
8.4 \\
7.4 \\
7.5 \\
3.1 \\
1.1\end{array}$ & $\begin{array}{r}11.9 \\
5.9 \\
6.2 \\
7.1 \\
1.5 \\
.8\end{array}$ \\
\hline 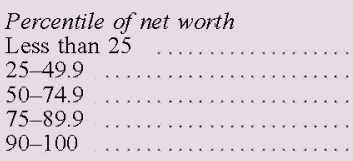 & $\begin{array}{r}9.5 \\
11.9 \\
11.8 \\
9.9 \\
9.6\end{array}$ & $\begin{array}{r}9.5 \\
11.4 \\
11.0 \\
9.2 \\
11.5\end{array}$ & $\begin{array}{l}11.8 \\
15.1 \\
12.4 \\
11.6 \\
11.1\end{array}$ & $\begin{array}{r}10.3 \\
13.3 \\
10.5 \\
10.6 \\
8.4\end{array}$ & $\begin{array}{r}14.4 \\
5.5 \\
3.1 \\
2.3 \\
1.8\end{array}$ & $\begin{array}{r}14.5 \\
8.2 \\
4.4 \\
2.4 \\
.7\end{array}$ & $\begin{array}{r}16.1 \\
9.8 \\
5.5 \\
1.0 \\
2.4\end{array}$ & $\begin{array}{r}17.7 \\
7.2 \\
3.6 \\
.8 \\
.3\end{array}$ \\
\hline $\begin{array}{l}\text { Housing status } \\
\text { Owner } \ldots \ldots \ldots \ldots \ldots \ldots \ldots \ldots \ldots \\
\text { Renter or other } \ldots \ldots \ldots \ldots \ldots \ldots \ldots\end{array}$ & $\begin{array}{r}13.6 \\
4.7\end{array}$ & $\begin{array}{r}13.0 \\
5.1\end{array}$ & $\begin{array}{r}15.8 \\
5.3\end{array}$ & $\begin{array}{r}13.9 \\
3.5\end{array}$ & $\begin{array}{r}3.6 \\
11.1\end{array}$ & $\begin{array}{r}5.1 \\
11.5\end{array}$ & $\begin{array}{r}6.1 \\
12.8\end{array}$ & $\begin{array}{r}4.3 \\
14.0\end{array}$ \\
\hline
\end{tabular}

NotE. The aggregate measure is the ratio of total debt payments to total income for all families. The median of family ratios is the median of the distribution of ratios calculated for individual families. Also see note to table 1.

percent of families with such assets and the level of their holdings served to push up their share of total financial assets. The homeownership rate grew 1.5 percentage points from 1998 to 2001 , and the typical home value rose more than 12 percent. Nonetheless, the growth of financial assets outpaced other assets as a share of total assets.

The percent of families with any sort of debt went up about 1 percentage point, and median debt for debtor families rose almost 10 percent. Even so, the growth of assets was faster than the growth of debt, and the aggregate leverage ratio consequently declined. Debt payments relative to income showed broad signs of decline over demographic groups. However, increased problems with late payments for a few groups suggest they face more serious credit distress.

Median and mean incomes rose substantially from 1998 to 2001, but as in the case of net worth, there were very different growth rates for various demographic groups. The income data show particularly strong returns to education. Families headed by persons with a college degree had substantially larger increases in income than other families.

\section{APPENDLX: SURVEY PROCEDURES AND STATLSTICAL MEASURES}

Detailed documentation of the SCF methodology is available elsewhere. ${ }^{3.3}$ The 2001 data used here are derived from the final internal version of the survey information. Data from this survey, suitably altered to protect the privacy of respondents, along with additional tabulations of data from the surveys beginning with 1989, will be available in February 2003 at www.federalreserve.gov/pubs/oss/oss2/ scf200lhome.html. Links to the data used in this article for earlier periods are available on that site. Results reported in this article for earlier surveys may differ from the results reported in earlier articles because of additional statistical processing, correction of data errors, revisions to the survey weights, conceptual changes in the definitions of variables used in the articles, and adjustments for inflation.

33. See Arthur B. Kennickell, "Wealth Measurement in the Survey of Consumer Finances: Methodology and Directions for Future Research," www.federalreserve.gov/pubs/oss/oss2/method.html (May 2000 ), and references cited in that paper. 
As a part of the general reconciliations required for this article, the survey data were compared with many external estimates, a few of which are mentioned in the text. Generally, the survey estimates correspond fairly well to external estimates. One particularly important comparison is between the $\mathrm{SCF}$ and the Federal Reserve's flow of funds accounts for the household sector. This comparison suggests that when the definitions of the variables in the two sources can be adjusted to a common conceptual basis, the estimates of totals in the two systems tend to be close. The data series in the SCF and in the flow of funds accounts usually show very similar growth rates. ${ }^{34}$ In general, the only data from the SCF that can be compared with those of other surveys are the medians because of the special design of the SCF sample.

\section{Definition of Family in the SCF.}

The definition of "family" used throughout this article differs from that typically used in other government studies. In the SCF, a household unit is divided into a "primary economic unit" (PEU) - the family - and everyone else in the household. The PEU is intended to be the economically dominant single individual or couple (whether married or living together as partners) and all other persons in the household who are financially interdependent with that person or those persons. In other government studies-for example, those of the Bureau of the Census - an individual is not considered a family.

This report also designates a head of the PEU, not to convey a judgment about how an individual family is structured but as a means of organizing the data consistently. If a couple is economically dominant in the PEU, the head is the male in a mixed-sex couple and the older person in a same-sex couple. If a single individual is economically dominant, that person is designated as the family head in this report.

\section{The Sampling Techniques}

The survey is expected to provide a core set of data on family assets and liabilities, The major aspects of the sample design that address this requirement have been fixed since 1989. The SCF combines two tech-

34. For details on how these comparisons are structured and the results of comparisons for earlier surveys, see Rochelle $\mathrm{L}$. Antoniewicz, "A Comparison of Flow of Funds Accounts and the Survey of Consumer Finances," www.federalreserve.gov/pubs/oss/ oss $2 /$ method.html, October 2000 . niques for random sampling. First, a standard multistage area-probability sample (a geographically based random sample) is selected to provide good coverage of characteristics, such as home ownership, that are broadly distributed in the population.

Second, a supplemental sample is selected to disproportionately include wealthy families, who hold a relatively large share of such thinly held assets as noncorporate businesses and tax-exempt bonds. Called the list sample, this group is drawn from a list of statistical records derived from tax returns. These records are used under strict rules governing confidentiality, the rights of potential respondents to refuse participation in the survey, and the types of information that can be made available. Individuals listed by Forbes magazine as being among the wealthiest 400 people in the United States are excluded from sampling.

Of the 4,449 interviews completed for the 2001 $\mathrm{SCF}, 2,917$ were from the area-probability sample, and 1,532 were from the list sample; the figures for 1998 are 2,780 from the area-probability sample and 1,519 from the list sample. The 1998 survey represents 102.6 million families, and the 2001 survey represents 106.5 million families. ${ }^{.5}$

\section{The Interviews}

Only minor changes to the SCF questionnaire have been made since 1989, and then only in response to financial innovations or to gather additional information on the structure of family finances. Thus, the data obtained by the five surveys conducted over this period are highly comparable.

The generosity of families in giving their time for interviews has been crucial to the SCF. In the 2001 $\mathrm{SCF}$, the median interview required about eighty minutes. However, in some particularly complicated cases, the amount of time needed was substantially more than two hours. The role of the interviewers in this effort is also critical. Without their dedication and perseverance, the survey would not be possible.

The SCF interviews were conducted between the months of May and December in each survey year by NORC, a social science and survey research organization at the University of Chicago (formerly the National Opinion Research Center at the University of Chicago). The great majority of interviews were obtained in person, although interviewers were allowed to conduct telephone interviews if that was

35. The 1992 survey represents 95.9 million families, and the 1995 survey represents 99.0 million families. 
more convenient for the respondent. In the surveys beginning with 1995 , interviewers used a program running on laptop computers to administer the survey and collect the data.

The use of computer-assisted personal interviewing has the great advantage of enforcing systematic collection of data across all cases. The computer program developed to collect the data for the SCF was tailored to allow the collection of partial information in the form of ranges whenever a respondent either did not know or did not want to reveal an exact dollar figure.

The response rate in the area-probability sample is more than double that in the list sample. In both 1998 and 2001, about 70 percent of households selected for the area-probability sample actually completed interviews. The overall response rate in the list sample was about 30 percent; in the part of the list sample likely containing the wealthiest families, the response rate was only about 10 percent. Analysis of the data confirms that the tendency to refuse participation is highly correlated with net worth.

\section{Weighting}

To provide a measure of the frequency with which families similar to the sample families could be expected to be found in the population of all families, an analysis weight is computed for each case accounting for both the systematic properties of the sample design and for differential patterns of nonresponse. The SCF response rates are low by the standards of other major government surveys. However, unlike other surveys, which also almost certainly have differential nonresponse by wealthy households, the SCF has the means to adjust for such nonresponse. A major part of SCF research is devoted to the evaluation of nonresponse and adjustments for nonresponse in the analysis weights of the survey. ${ }^{36}$

For this article, the weights of a small number of cases have been further adjusted to diminish the possibility that the results reported could be unduly affected by influential observations. Such influential observations were detected with a graphical technique that allows inspection of the weighted distribution of the underlying data. Most of the cases

\footnotetext{
36. The weights used in this article are based on a nonresponseadjusted weight that accounts for differential nonresponse across racial and ethnic groups by home ownership. See Arthur B. Kennickell, "Revisions to the SCF Weighting Methodology: Accounting for Race/Ethnicity and Homeownership" (Board of Governors of the Federal Reserve System, December 1999), available at www.federalreserve.gov/pubs/oss/oss $2 /$ method.html.
}

found were holders of an unusual asset or liability or were members of a demographic group in which such holdings are rare. These weight adjustments are likely to make the key findings in this article more robust.

\section{Sources of Error:}

Errors may be introduced into survey results at many stages. Sampling error - the variability expected in estimates based on a sample instead of a census - is a particularly important source of error. Such error can be reduced either by increasing the size of a sample or, as is done in the SCF, by designing the sample to reduce important sources of variability. Sampling error can be estimated, and for this article we use replication methods to do so.

Replication methods draw samples from the set of actual respondents in a way that incorporates the important dimensions of the original sample design. In the SCF, weights were computed for all the cases in each of the selected replicates. For each statistic for which standard errors are reported in this article, the weighted statistic is estimated using the replicate samples, and a measure of the variability of these estimates is combined with a measure of the variability due to imputation for missing data to yield the standard error. The estimation of the standard errors reported in this article employed a variation on the procedure used to compute the corresponding estimates reported in earlier articles on the survey; this variation concerns an adjustment made in the merging of the area-probability and list sample observations within each replicate sample, and it has the effect of moderating the effects of situations in the replicate samples that would not have been allowed in the actual sample. ${ }^{37}$

Other errors include those that interviewers may introduce by failing to follow the survey protocol or misunderstanding a respondent's answers. SCF interviewers are given lengthy, project-specific training to minimize such problems. Respondents may introduce error by interpreting a question in a sense different from that intended by the survey. For the SCF, extensive pretesting of questions and thorough review of the data tends to reduce this source of error.

Nonresponse - either complete nonresponse to the survey or nonresponse to selected items within the survey - may be another important source of error.

37. For more information on the revised standard error estimates, see Arthur B. Kennickell, "Revisions to the Variance Estimation Procedure for the SCF" (October 2000), at www.federalreserve.gov/ pubs/oss/oss $2 /$ method.html. 
As noted in more detail above, the SCF uses weighting to adjust for differential nonresponse to the survey. To address missing information on individual questions within the interview, the SCF uses statisti- cal methods to impute missing data; the technique used makes multiple estimates of missing data to allow for an estimate of the uncertainty attributable to this type of nonresponse. 